\title{
SUPPL Y-SIDE CONSEQUENCES OF SOCIAL SECURITY REFORM: IMPACTS ON SAVING AND EMPLOYMENT
}

\author{
Barry Bosworth* \\ Gary Burtless \\ CRR WP 2004-01 \\ January 2004 \\ Center for Retirement Research at Boston College \\ 550 Fulton Hall \\ 140 Commonwealth Ave. \\ Chestnut Hill, MA 02467 \\ Tel: 617-552-1762 Fax: 617-552-1750 \\ http://www.bc.edu/crr
}

*Barry Bosworth and Gary Burtless are both senior fellows at The Brookings Institution. The research
reported herein was performed pursuant to a grant from the U.S. Social Security Administration (SSA) to
the Center for Retirement Research at Boston College (CRR). The opinions and conclusions are solely
those of the authors and should not be construed as representing the opinions or policy of SSA or any
agency of the Federal Government or of the CRR. The authors would like to acknowledge the research
assistance of Alice Henriques, Benjamin Keys, Pablo Montagnes, Claudia Sahm, and Dan Theisen.

(C) 2004, by Barry Bosworth and Gary Burtless. All rights reserved. Short sections of text, not to exceed two paragraphs, may be quoted without explicit permission provided that full credit, including $\odot$ notice, is given to the source. 


\section{About the Center for Retirement Research}

The Center for Retirement Research at Boston College, part of a consortium that includes parallel centers at the University of Michigan and the National Bureau of Economic Research, was established in 1998 through a grant from the Social Security Administration. The goals of the Center are to promote research on retirement issues, to transmit new findings to the policy community and the public, to help train new scholars, and to broaden access to valuable data sources. Through these initiatives, the Center hopes to forge a strong link between the academic and policy communities around an issue of critical importance to the nation's future.

\section{Center for Retirement Research at Boston College}

550 Fulton Hall

140 Commonwealth Ave.

Chestnut Hill, MA 02467

phone: 617-552-1762 fax: 617-552-1750

e-mail: crr@bc.edu

http://www.bc.edu/crr

Affiliated Institutions:

American Enterprise Institute

The Brookings Institution

Massachusetts Institute of Technology

Syracuse University

Urban Institute 


\title{
Supply-Side Consequences of Social Security Reform: Impacts on Saving and Employment
}

\author{
by \\ BARRY BOSWORTH AND GARY BURTLESS
}

\begin{abstract}
Pension reform can potentially increase saving and improve incentives for labor force participation later in life. We investigate whether these effects are likely to occur and the potential size of the effects on private and total saving and on employment past age 55. Our survey of existing evidence and new empirical analysis focus on three issues: The possible reduction in other government saving if more assets are accumulated in a public retirement program; the reduction in non-pension private saving if assets are accumulated in new private retirement accounts; and the increase in old-age labor supply that could occur if Social Security benefits are reduced.

We find mixed evidence that faster accumulation of assets in public or private retirement funds would produce higher public and private saving. Using the most optimistic estimates of the public saving response to faster accumulation in public retirement funds, we find advance funding will cause a big increase in aggregate saving and future national income. However, international evidence suggests governments are likely to offset a large percentage of public pension fund accumulation by reducing saving in other government accounts. The evidence on private saving suggests that savers tend to offset faster accumulation of assets in pension accounts with lower saving in non-pension accounts. Most empirical estimates of the labor supply response to Social Security reductions imply the response will be small. Even using unrealistically high estimates of responsiveness, we find that a one-third cut in benefits will add less than 3 percent to the future labor force.
\end{abstract}




\section{Supply-Side Consequences of Social Security Reform: Impacts on Saving and Employment}

The Social Security system has been remarkably successful in lifting relative incomes and alleviating poverty among the nation's elderly. But the population of the United States, like that of other industrialized countries, is growing older. Between 1950 and 2000 the percentage of Americans past age 65 increased by half, rising from 8.1 percent to 12.4 percent of the total population. People who are at least 65 years old will constitute more than one-fifth of the U.S. population by 2050 . The increasing share of the aged in the population will place strains on the government budget because the elderly finance much of their consumption with transfers financed by taxpayers. The actuaries of the Social Security and Medicare programs make regular forecasts of the long-term spending needs of the two programs. Their mid-range forecasts published in 2001 suggest that combined outlays on the Social Security and Medicare programs will climb inexorably over the next 50 years, increasing from 5.5 percent of GDP in 2000 to 11.4 percent of GDP in 2050.

Most people knowledgeable about the U.S. retirement system recognize it will eventually have to be reformed to restrain the growth of future costs. Individual retirement accounts are a common feature in many proposals to reform Social Security. For example, in December 2001 President Bush's Commission to Strengthen Social Security issued a report containing three reform proposals. A crucial element in all three plans was the introduction of new individual defined-contribution pension accounts. Although a principal goal of reform is to restore or preserve the long-term solvency of the national pension system, proponents of individual accounts also argue that replacing traditional defined-benefit pensions with individual investment accounts can have two other advantages for a nation's economy. First, the accumulation of investments in millions of individual retirement accounts will add to private and national saving, improving the rate of domestic capital formation or the accumulation of a nation's overseas assets. 
Second, the structure of defined-contribution pensions provides better incentives for older workers to remain in the labor force, at least in comparison with the incentives embedded in traditional defined-benefit pensions. Unlike a traditional pension, which can discourage workers from continuing to work after the early or normal retirement age, a defined-contribution pension is more neutral with regard to encouraging retirement at specific ages. Under these circumstances, many advocates of defined-contribution pensions believe that reform of the traditional pension system can improve labor market incentives and encourage Americans to work later in life. This in turn will reduce the burden of population aging, because fewer old people will be retired and drawing support from active workers; more old people will be working and contributing to the national pension system.

In sum, partial replacement of the traditional unfunded pension system with a new system of private investment accounts can potentially increase saving and improve incentives for labor force participation later in life. Both of these responses would lead to higher levels of future incomes. In this paper we investigate whether these effects are likely to occur and the potential size of the effects on private and total saving and on employment past age 55. The remainder of the paper is divided into four sections. In the next section we evaluate evidence on the likely effects of higher fund accumulation within a public pension program. We consider whether such accumulation will be offset by greater dissaving in other government accounts and then assess the net impact on overall public saving. The following section evaluates the overall private saving response to extra saving in private pension accounts. In both these sections we provide estimates of the impact of faster fund accumulation on overall saving, the capital stock, and future national income. The third section weighs evidence on the past effect of the Social Security system on labor force participation among the elderly. In this section we develop new estimates of the potential impact of Social Security reform on future labor supply. The paper ends with a brief summary of conclusions.

\section{Advance funding and saving in the public sector}

An advance funded pension program potentially offers several advantages over a pay-asyou-go (PAYGO) system. ${ }^{1}$ An important one is the possibility that increased funding would lead to a rise in national saving and capital formation unless it is offset by reduced public or private

\footnotetext{
${ }^{1}$ The arguments for and against a funded public program are evaluated more fully in Hemming (1999).
} 
saving outside of the pension system. Advocates of advance funding disagree about whether the reserves of a funded system should be publicly or privately managed. If funds are accumulated in a single government-managed fund, officials must decide how to allocate assets across a variety of investment options. If instead funds are accumulated in millions of individual investment accounts, decision making over asset allocation is left up to individual workers. Public and private plans involve much different approaches to managing investment risks. In a national defined-benefit plan, the investment risks can be spread among millions of active and retired workers and across multiple generations. Unexpectedly poor returns on contributions can lead to adjustments in contributions as well as benefits. In private defined-contribution accounts, financial risks are largely or entirely borne by individual contributors.

The focus of this and the following sections is on the potential of pension funding to increase aggregate saving. Many who advocate a shift toward advance funding assume the growing surpluses of a new or reformed pension fund will lead to increased national saving. This assumption is crucial if funding is to reduce the burden of population aging on future workers, because unless it induces an increase in saving, reform will have little effect on the size of the future capital stock or national income. While the impact of pensions on saving is a much studied topic, most of the historical debate has centered around the question of whether the creation of public PAYGO systems has reduced national saving. ${ }^{2}$ Here we consider whether a shift from PAYGO toward advance funding will alter national saving.

Our analysis examines two alternative approaches to increased pension funding: (1) Increased funding that takes place in the existing public pension system by bringing forward the tax increases that will be required to maintain future solvency; and (2) Creation of a new system of mandatory individual retirement accounts owned and managed in the private sector. Under the latter reform, funds accumulated in the individual accounts would finance future private pensions that offset some or all of the anticipated Social Security benefit cuts needed to maintain solvency of the public PAYGO system. In each case, it is important to consider both the budget reaction within the government sector and the saving response of private individuals to determine the impact of the pension reform on aggregate saving. The remainder of this section considers the public saving response to greater advance funding in the public pension system. The next section examines private savers' response to funding in a new private pension program.

\footnotetext{
${ }^{2}$ This literature is reviewed and summarized in CBO (1998) and Atkinson (1987).
} 
Public sector funding. If a legislature decides to increase pension funding within the existing public program by accelerating future tax increases, there will be no change in the level of promised future benefits. It is the size of the credible benefit promise - the future liabilities of the system - that should influence private saving, not the amount of saving within the fund. Unless the funding of future liabilities makes future benefit promises more credible, greater advance funding in the public pension system should have little impact on private saving.

Thus, the critical issue for national saving involves the response of saving within the government sector itself. The public saving response to advance funding depends to some extent on whether the pension system represents a function distinct from the rest of the public budget. If the public pension program is seen as just one among many similar government transfer programs, there may be no reason to separate this spending commitment from other government activities. Hence. the pension system's revenues will be regarded as part of total revenues when the legislature struggles to allocate scarce resources among competing claims. From this perspective, a larger pension fund surplus is likely to be offset within the government budget as a whole, either by a reduction in non-pension taxes or an increase in non-pension spending.

There is another possibility, of course. The revenues and obligations of the public pension system may be regarded as quite independent and distinct from other government revenues and functions. Several OECD countries have an explicit goal of funding a portion of their public pension obligations. ${ }^{3}$ State and local governments in the United States attempt to fund their employee pension obligations outside their operating fund accounts. A commitment to differentiate between the retirement accounts and other budget accounts is not sufficient, however, to automatically produce higher public saving when a government consciously increases its funding of future pension obligations. The government must also avoid the temptation to borrow the surplus of the pension system to finance spending in its other budget accounts. That is, the funding balance of the non-retirement accounts must be determined independently of the balance of the pension fund. ${ }^{4}$ Otherwise, an increase in the pension account

\footnotetext{
${ }^{3}$ The experiences of Canada, Japan, and Sweden are reviewed in Munnell and Ernsberger (1989).

${ }^{4}$ It is uncommon for the states to directly transfer funds from the pension system to the general budget, but it is possible for them to change the actuarial assumptions used to compute future liabilities, thereby reducing required contributions to the fund (Munnell and Sundén, 2001).
} 
surplus would not produce an increase net public saving, and governments would have simply used their pension payroll tax to finance current activities.

In an earlier paper, we explored the empirical evidence regarding public-sector saving by performing two statistical analyses (Bosworth and Burtless, 2003). In one analysis we examined the response of U.S. state governments to the accumulation of reserves in their funded employee pension programs. In the second, we used data compiled under the international system of national accounts (SNA) to examine the relationship between saving within national governments' social insurance accounts and the non-retirement budget accounts of twelve OECD countries.

The two empirical analyses produced conflicting conclusions about the capacity of governments to add to their overall saving when they built up larger reserves in their public retirement systems. Whereas the U.S. states appear to have successfully funded their pension obligations and isolated this funding from the remainder of state budgets, the international experience and that of the U.S. federal government suggest that increased accumulations in public retirement funds are largely offset by bigger deficits or smaller surpluses in non-pension accounts.

Evidence from state pension systems. Our analysis of U.S. state experience was based on Census Bureau data covering budgets, assets, and debts of 48 states over the period from 1977 to 1999. Data from a companion survey provided information on the finances of the public employee retirement programs. The combined data make it straightforward to tabulate accurately the revenues and spending of the retirement and non-retirement accounts of American state governments.

State and local government employee pension plans are far from trivial, either in scope or asset holdings. These plans covered 13.9 million active workers and made pension payments to 6.3 million beneficiaries in $2000 .^{5}$ At the end of that year the market value of the assets held by state and local government employee pension funds amounted to $\$ 2.3$ trillion, or about half the total held in U.S. private employer-provided pension funds. A mid-2001 survey of state and local pension plans covering 9.3 million workers found that the actuarial value of the plans'

\footnotetext{
${ }^{5}$ Current U.S. law compels private employers, but not state and local government employers, to participate in the Social Security system. However, most state and local governments voluntarily participate in the federal Social Security program.
} 
accrued liabilities was $\$ 1.5$ trillion while the plans' financial reserves amounted to $\$ 1.6$ trillion, implying an average funding ratio of 104 percent of discounted liabilities (Harris, 2002).

States' total contributions to their pension accounts, measured as a share of U.S. national income, have been stable over the past quarter century. Essentially all of the growth in pension fund assets has come from the investment income earned on the funds' reserve portfolios. That income consists of interest, dividends, and realized capital gains, but it excludes unrealized capital gains. Expenditures, which include benefit payments and administrative expenses, grew from 0.4 percent of national income in 1977 to 0.9 percent by 1999. During the same period, the annual net accumulation - or annual saving - in the funds increased from 0.5 percent to 1.8 percent of national income.

In our earlier paper we estimated a straightforward model of the relationship between the fiscal balance of a state's non-retirement accounts, $B$, and the net saving that occurs within the state's pension program, $P E N$. Annual changes in state personal income were included to adjust for cyclical fluctuations in the state economy: ${ }^{6}$

$$
\text { (1) } B_{i t}=\alpha_{i}+\beta_{i} P E N_{i t}+\delta_{i} \Delta \mathrm{Y}_{i t} \text {, }
$$

where

$B_{i t} \quad=$ Balance in the non-retirement budget accounts of the $i$ th state in year $t$;

$P E N=$ Net accumulation within the state's pension account; and

$\Delta \mathrm{Y} \quad=$ Percentage change in real personal income.

The net accumulation of the pension fund was measured as total contributions to the fund, plus investment income, less total expenditures. The measure of investment income included realized capital gains or losses on asset sales, interest, and dividends. The annual balance in a state's non-retirement account was computed by excluding investment income of the pension account from revenues, and redefining state expenditures to exclude pension benefits and include state contributions to the pension fund. Since state contributions to the pension fund represent payments for accruing new liabilities, they reflect a component of current employee compensation (like wages or sickness pay) and should be treated as a current expense of government.

\footnotetext{
${ }^{6}$ The personal income data were deflated by the price index for national gross domestic product.
} 
The coefficient on pension accumulation in equation $1, \beta$, measures the extent to which changes in the pension account are offset by associated changes in net state spending in other budget accounts. Since any potential offset need not be contemporaneous, our specification also allowed for lagged effects of pension fund accumulations. Current and lagged percentage changes in real state aggregate income were included to control for business-cycle effects on state-level non-pension spending. Equation 1 was estimated using a fixed-effects model that allows for a shift in the constant term, $\alpha_{i}$, for each state. With allowance for the degrees of freedom used up to measure lags, we had 1,056 annual observations covering 48 states over the period from 1978 through 1999.

The critical coefficients for assessing the impact of state pension accumulation on overall state budgetary balances are those on contemporaneous and lagged pension saving. In our basic specification, the coefficients imply a small and statistically insignificant offset of about 8 percent of the accumulation over a two-year period. In other words, when an average state pension fund accumulates an additional $\$ 100$ in extra reserves, the deficit in the state's nonpension budget accounts eventually increases about $\$ 8$. The estimates thus indicate that the additional accumulation of funds in states' pension accounts has almost no impact on the net balance of the rest of state budgets. A higher accumulation in state pension funds is almost fully reflected as higher state saving.

Our basic finding was robust across a variety of statistical specifications. For example, the coefficient estimate was unaffected by inclusion or exclusion of procedures to control for error autocorrelation. Nor was the coefficient affected by statistical controls to distinguish between states with strong and weak versions of a balanced budget rule in their constitutions. In short, the results using a variety of specifications suggest that there is virtually no impact of incremental accumulations in state pension funds on the fiscal stance of the remainder of state budgets. Extra pension accumulations are not offset by higher dissaving in other state budget accounts. It follows that the accumulation of extra savings within a state pension fund translates into additions in state government savings in the aggregate. The political process within state governments does not undermine efforts of states to fund their employee pension obligations with real and sustained additions to state public saving. The result is a substantial contribution of state pension saving to U.S. public saving. Over the past quarter century, saving within state and local government pension funds has averaged more than one percent of U.S. national income, 
while net saving within state budget accounts outside of pension programs has averaged about 0.3 percent of national income.

Cross-national evidence. The cross-national evidence on the effects of public pension funding on overall public saving is not so reassuring. Partial funding of public pension liabilities has been a policy goal of several OECD countries, including Canada, Finland, Japan, and Sweden. The United States has also accumulated a sizeable Social Security reserve over the past two decades. The face value of U.S. Social Security reserves at the end of December 2002 was $\$ 1.38$ trillion, or about 13 percent of U.S. GDP.

However, as discussed above, it is not obvious whether large fund accumulations in national public pension programs have actually contributed to public saving. Even though the administrator of a public fund may have used pension system surpluses to purchase marketable investment assets, the net effect of this transaction on public saving depends on budgetary actions outside of the pension system itself. If an increase in the employment tax and a larger surplus in the pension account lead to a greater willingness on the part of legislators to tolerate deficits in non-retirement budget accounts, there may be no net increase in public saving even though pension system reserves are growing rapidly. Smetters (2002) argues, for example, that legislators regard the retirement trust funds as a cheap source of funds relative to alternative revenue sources, such as a tax increase.

The recent history of U.S. Social Security surpluses reflects this ambiguity. Beginning with enactment of the 1983 Social Security amendments, the U.S. public retirement system began to generate significant surpluses as a result of higher dedicated taxes, rising labor force participation, and slow growth in the beneficiary population. In spite of the growing Social Security surpluses, the overall federal budget position was one of sustained deficits throughout the 1980s. Arguably, the surpluses in the Social Security Trust Fund were simply appropriated to finance greater federal spending or allow lower non-Social-Security taxes.

This pattern changed noticeably in the 1990s when ever-growing Social Security surpluses were matched by significant reductions in the deficit of the non-retirement accounts. This was also an era when some federal office holders argued for a target of a balanced non-Social-Security budget. If such a target were achieved, additions to the Social Security reserves would have been fully reflected as extra public saving. Congress formally excluded the Social Security accounts from the "on-budget" federal accounts as a method of increasing the separation between the 
retirement and other budget accounts. Since 2001 the situation has reverted back to the pattern of the 1980s. Large surpluses in the Social Security Trust Fund are more than offset by even larger deficits in the rest of the budget. The U.S. experience thus provides weak evidence on the effects of public pension surpluses on the overall budget stance of the government. This qualitative uncertainty also emerges from a formal statistical analysis of the post-World-War-II U.S. experience (see Bosworth and Burtless, 2003).

Information from countries in addition to the United States can be used to assess the impacts of advance funding in public pension accounts. In previous analysis we assembled information for 13 OECD countries, including the United States, over the period of 1970-2000 (Bosworth and Burtless 2003). Our data set distinguished public saving within the social insurance sector from that in the remainder of general government. Our sample included a total of 305 country-year observations. ${ }^{7}$

Over the 30-year period, average saving within the countries' social insurance accounts ranged from more than two percent of national income in Sweden and Finland to less than one percent in Germany and France. The structure of the estimated fixed-effect regression was basically the same as that described for the U.S. states (equation 1 above). The non-retirement saving balance was regressed on the balance of the social insurance funds. We expected the coefficient on the social insurance fund balance to range between zero (reflecting no offset) and -1 (reflecting full offset of extra saving in the social insurance accounts). We included the rate of change in GDP and the unemployment rate to account for cyclical influences on national budget policy.

The results based on cross-national evidence offer a striking contrast to the results obtained for U.S. state governments. The coefficients of our basic cross-national model showed a very strong inverse relationship between the current and prior year's saving within the social insurance account and the current balance for non-retirement budgetary accounts. Our estimate of the coefficient on the social insurance fund balance was not statistically significantly different from -1, reflecting a full offset of social insurance fund saving in other government accounts. This basic result was sensitive to correction for autocorrelation in the residuals, however. When

\footnotetext{
${ }^{7}$ The countries were Austria, Canada, Denmark, Finland, France, Germany, Italy, Japan, the Netherlands, Portugal, Spain, Sweden, and the United States. The measures of saving were computed as current revenues less current expenditures and thereby excluded the capital account.
} 
we corrected for autocorrelation the model yielded a more favorable offset of -0.57 , a result that was significantly different from both zero and -1.0 at the 0.1 level. This implies a net positive effect on overall public saving of about 40 percent of the extra pension accumulation. The results were also sensitive to the sample of countries included in the analysis. The coefficient on the social insurance balance varied from -0.8 (when the sample excluded Finland) up to -0.2 (when it excluded Sweden). When the sample of countries was restricted to the five countries that at one time or another had an announced goal of accumulating a large pension reserve, the estimated offset was -0.64 , very similar to the autocorrelation-corrected results for the larger sample. In all specifications and for nearly all samples we examined, the cross-national evidence implied sizeable offsets in the form of lower non-social-security public saving when there are additions to public pension fund assets. This verdict is less favorable than the one reached by Munnell and Ernsberger (1989) who concluded that Japan and Sweden had succeeded in isolating their pension funds from the rest of their public budgets.

Reconciling state and cross-national evidence. In our earlier study we considered a variety of possible explanations for the striking discrepancy between the results based on state behavior within the United States and results based on the behavior of nation states, including the U.S. federal government. One explanation is that there is an important difference between the motivations and constraints facing state legislators, on the one hand, and office holders in national governments, on the other. State lawmakers may be keenly aware of the potential burden imposed by pension obligations on future taxpayers. For the most part they have followed a conservative strategy in pre-funding those obligations. This conservatism is driven in part by states' continuing need to borrow funds in U.S. capital markets. States which follow conservative financing principles in their fiscal accounts can obtain favorable borrowing rates in capital markets, reducing the credit cost of public investment projects and helping hold down state's borrowing costs during recessions, when state operating budgets are often in deficit.

Perhaps most crucially, state and local governments within the United States are faced with highly mobile tax-paying populations. They must be concerned that tax-paying residents will move to another jurisdiction if state taxes are not closely aligned to the expected benefits provided by the state government. If a shortfall in current pension reserves causes state legislators to push up tax rates in order to pay for the pensions of already-retired employees, the state's high tax burden will in effect pay for labor services that were rendered in the past. The 
current tax burden will not reflect the flow of state government services going to current residents. Within the United States, taxpayers are free to move to another state where tax burdens are more closely aligned to the current flow of state-provided services. Nation states probably have less reason to be worried that taxpayers will vote with their feet by moving to another country. ${ }^{8}$

In contrast, the debate over budget policy at the national level is driven by a different set of considerations. National governments use fiscal policy to promote economic stabilization, embracing deficit spending in recessions and fiscal stringency during booms. In contrast, no state government within the United States has recently attempted to adjust its budget balance to achieve macroeconomic stabilization goals. The focus on the economy-wide economic effects of fiscal policy at the national level may encourage the aggregation of national budget accounts into a single net measure of the cash flow balance. Thus, while Congress has passed laws aimed at separating the Social Security system from the so-called "on-budget" accounts, this distinction is widely ignored in public debate over the government's economic policies.

Implications for the national economy. The government saving response to additional accumulations in public pension programs obviously has important implications for assessing the effects of an advance funding policy that depends on accumulation of funds within a government-administered pension plan. If the extra accumulation in the pension fund adds to overall public saving, advance funding can boost aggregate saving and increase economic growth, reducing the burden of population aging on active workers (Aaron, Bosworth, and Burtless, 1989; and Bosworth, Burtless, and Sahm, forthcoming). However, if the additional accumulation is offset by larger deficits or smaller surpluses in other government accounts, the impact on public and aggregate saving will be modest or negligible.

We can illustrate the implications of the differing estimates of public saving responsiveness with a macroeconomic growth model. A growth model is simply a set of definitions and economic equations in which variations in the level of national saving have computable effects on additions to the capital stock and the future course of national income.

\footnotetext{
${ }^{8}$ However, even nation states must worry about adverse effects on labor supply and aggregate earnings if pension contributions and the pension benefit formula provide poor incentives for workers to seek employment in the social-security-covered sector.
} 
The model we use here is a standard neoclassical growth model that was described in detail in Bosworth and Burtless (1997 and 2000).

We also need to consider the consequences of different public saving responses within the context of a specific reform plan that incorporates the new advance funding within the public pension system. We consider a reform plan that we have evaluated in previous work (Aaron, Bosworth, and Burtless, 1989; and Bosworth and Burtless, 2000) in which the payroll tax is periodically increased to maintain close actuarial balance over a 75 -year horizon. ${ }^{9}$ The actuarial balance is simply the difference between the present discounted value of future income less the present discounted value of future costs. ${ }^{10}$ Recent OASDI trustee's reports have shown an actuarial deficit equal to about two percent of payroll.

The Social Security system already has large annual surpluses, so an immediate increase in payroll tax rates to achieve actuarial balance would accelerate the current growth of the trust fund. For simplicity, we have assumed that Social Security benefits will be maintained at the level promised under current law, and all of the adjustment needed to bring the system to longterm solvency is achieved by increasing payroll tax burdens on active workers. Using the economic and demographic assumptions of the OASDI Trustees' 2001 Annual Report, long-term actuarial balance could be achieved if the combined employer-employee payroll tax were increased by about 2.2 percentage points in 2004. Periodic increases in the payroll tax will also be needed in later years, because in the future the 75-year planning horizon will include additional years after 2076 when OASDI benefit payments are much larger than revenues. Our calculations suggest that if the payroll tax rate were increased 2.2 percentage points in 2004, the OASDI Trust Fund would accumulate an extra $\$ 110$ billion, or about 0.9 percent of GDP in that year. By 2075, the tax rate will have increased by about four percent of payroll and the trust fund will have stabilized at about 40 percent of GDP.

Table 1 shows our estimates of the impact of the additional Social Security saving on the wider economy under alternative assumptions about the government saving response to faster

${ }^{9}$ The 75 -year horizon is commonly used in the OASDI Trustees annual reports, and corresponds roughly to the life span of a worker entering the system in the current year.

${ }^{10}$ All discounting is performed using the projected rate of return earned by the Trust Fund over the 75-year horizon. In addition, the standard of actuarial balance requires sufficient reserves at the end of the period to pay one additional year's costs. In order to limit the frequency of any adjustments, no action is taken as long as discounted revenues exceed 95 percent of discounted costs. 
fund accumulation. The table shows the implications of three different assumptions about the public saving response function. In the top panel we assume that $\beta=0$, or in other words that government saving outside the pension fund is independent of the annual accumulation in the pension fund - there is no substitution between pension fund saving and the rest of the public budget. Under this assumption, the annual additions to the Social Security Trust Fund add directly to public and aggregate saving by $\$ 1$ for each $\$ 1$ of increase in the fund. This response function is consistent with the behavior of state lawmakers, who show little reaction in their non-pension saving to faster accumulation of state pension fund assets.

To perform the calculations we assume that the government budget, excluding Social Security, is in balance and the private saving rate is not affected by faster fund accumulation in the Social Security Trust Fund. In addition, we assume the increases in public pension fund saving are invested in the domestic economy. ${ }^{11}$ As expected, when $\beta=0$ the extra accumulations in the Social Security Trust Fund produce large increases in the future capital stock, GDP, and wages. The economy-wide wage rate is almost 4 percent above the baseline projection by 2020 and more than 10 percent higher by 2050. The increase in saving implies a lower level of aggregate consumption for almost two decades after 2000, through 2022, but the additions to the capital stock and real wages allow real consumption to rise 4.2 percent above the baseline path by 2050 . The increased capital accumulation drives down the rate of return on capital. In comparison with the baseline path of returns, the rate of return falls 6 percent by 2025 and almost 13 percent by 2050. Nonetheless, aggregate income and consumption are substantially higher after 50 years than would be the case if public saving remained zero over the projection period.

Not surprisingly, these effects are much smaller if accumulations in the trust fund are largely offset by the public saving response in non-pension government accounts. The middle panel in Table 1 shows the effect of assuming $\beta=-0.65$, the approximate response coefficient we found in five countries which have attempted to build up major reserves in their public pension systems. This estimate implies that only $\$ 0.35$ out of every $\$ 1$ added to public pension reserves is added to total government saving. The other $\$ 0.65$ is offset by larger deficits or smaller surpluses in other government accounts. This assumption means that saving, investment, and national income rise substantially more slowly compared with their baseline paths than is the

\footnotetext{
${ }^{11}$ Under an alternative assumption, some or all of the extra saving can be invested outside the United States. See Bosworth, Burtless, and Sahm (forthcoming).
} 
case when $\$ 1$ of additional trust fund accumulation results in $\$ 1$ of additional public saving. For example, in 2010 aggregate savings are only 8 percent higher under this assumption compared with the 25 percent increase that occurs when all additions to the trust fund represent net additions to government saving. In the near term the large assumed public saving response to faster accumulation has an advantage: Consumption only falls 0.3 percent in 2010 compared with the 1.0 percent decline that occurs if all additions to the trust fund represent additions to government saving.

The bottom panel shows changes in economic aggregates when 90 percent of extra accumulations in the trust fund are offset by larger deficits or smaller surpluses in other government accounts. Because the additions to future saving will be smaller, the future economy and wage bill will also be smaller, necessitating a larger payroll tax increase in 2004 to bring Social Security into close actuarial balance. ${ }^{12}$ In the near term the high public saving response coefficient means that Americans can enjoy higher aggregate consumption than when the response coefficient is smaller, but in the long run consumption is lower than it would be if all the additions to Social Security reserves represented additions to public saving. Instead of climbing 10 percent faster than the baseline path of wages, the economy-wide real wage rises only 1 percent faster than is forecast under the baseline assumptions. Clearly, uncertainty about the government saving response to faster accumulation in the Social Security Trust Fund makes the benefits of an advance funding policy highly uncertain.

\section{Advance funding and private saving}

A second approach to advance funding involves the full or partial replacement of the public PAYGO system with a new funded private system. One example of this kind of reform is the proposal of the presidential commission to redirect a fraction of current Social Security contributions into funded individual retirement accounts (President's Commission to Strengthen Social Security, 2002). On its face, the redirection of contributions would have little effect on aggregate national saving, since the surplus of the new private pension fund would be largely offset by an increased deficit or smaller surplus in the public sector pension system. The first

\footnotetext{
${ }^{12}$ The payroll tax increase is 2.4 percentage points when $\beta=-0.9$. The increase is just 2.2 percentage points when $\beta=0$ and $\beta=-0.65$. The simulations also incorporate the effect of future growth on wages and thus future benefit payments. The induced effects on benefits reduce the net financial gain to the retirement system, but the benefit increases are smaller and lag well behind the increase in tax receipts.
} 
requirement for a net addition to saving is that the shift to a funded system must produce a net increase in pension contributions out of current income or a net reduction in pension benefits to current beneficiaries. As we have seen, if pension reform is to add to national saving, it must involve some short-term sacrifice of public or private consumption. The President's commission did not propose a plan that would ensure one of these outcomes since it simply shifted funds from the government to private accounts.

We consider an alternative of introducing a new system of mandatory definedcontribution accounts as an addition to the existing system rather than as a partial substitute for it. Such a reform would have a greater likelihood of raising saving, but an important issue is the extent to which individuals would react to new accounts by reducing their accumulation in other retirement or household saving accounts. Many workers in the lower ranks of the income distribution have little or no financial wealth and save very little. For these low-income workers there may be little possibility that mandatory contributions to new pension accounts could be offset by reductions in other forms of saving. ${ }^{13}$ On the other hand, roughly 50 percent of U.S. workers currently participate in private, employer-sponsored pension plans. These workers include most people with large wealth holdings, and they account for an overwhelming percentage of total worker saving. For these individuals, the substitution possibilities are greater. Many workers required to make contributions to a new private account system can easily offset the mandatory contributions by making smaller contributions to their old pension or saving accounts.

The net saving effects of individual retirement accounts and other forms of retirement saving have been explored in a number of U.S. and Canadian studies. Much of this literature focuses on the voluntary response of saving to changes in tax incentives for retirement saving, so its findings may not be directly applicable when thinking about the effects of a new mandatory pension program. The studies are usually based on microeconomic data obtained from household surveys. Researchers who have studied these data reach different conclusions on the extent of substitution between retirement and non-retirement saving, in part because of formidable

${ }^{13}$ According to the 2001 Survey of Consumer Finances, the median financial assets of families in the lower half of the income distribution was less than $\$ 10$ thousand.,000. Of course, homeowners with few financial assets can often boost their current consumption through increased borrowing on their homes. Low-income renters can increase their credit card debt. In general, however, it is probably harder for 
statistical issues raised by the extreme heterogeneity of saving behavior at the household level. Households that take advantage of tax-preferred saving options may have a much greater propensity to save. Two surveys of the research on tax-preferred saving show the extent of disagreement within the economics profession. Poterba, Venti, and Wise (1998) conclude that the huge flow of funds into new retirement accounts largely represents net new saving, that is, household saving that would not have occurred in the absence of more generous tax preferences. In contrast, Engen, Gale and Scholz (1996) argue that the dominant effect of the tax preferences has been to induce substitution of new for old forms of saving, yielding little net impact so far on overall household saving (also see Gale, 1998, and Gustman and Steinmeier, 1999).

International evidence on the private saving response to pension reform is no more conclusive than the U.S. microeconomic evidence. Among the OECD countries, Great Britain has been most active in promoting a shift out of the public system in favor of funded private pensions. Granville and Mallick (2002) argue that the increase in occupational pension saving was totally offset by a decrease in other forms of British household saving. Slightly more optimistic results are obtained by Attanasio and Rohwedder (2003) who use microeconomic household data. Bailliu and Reisen (2000) report a weak positive correlation between the buildup of private pension assets relative to GDP and private saving for a sample consisting of six OECD and three non-OECD countries. However, the correlation was negative when they limited their sample to OECD countries. Samwick (2000) found a lower rate of saving in countries with extensive PAYGO systems, but he was unable to find consistent evidence of higher saving rates after reform.

In our earlier paper we supplemented the existing literature with a statistical examination of cross-national saving patterns at the aggregate level (Bosworth and Burtless, 2003). We used data from the national accounts and the flow of (financial) funds accounts to create estimates of private saving that are divided into three components: corporate saving (retained earnings), saving within formal retirement accounts, and non-retirement saving. We were able to make appropriate calculations of pension and non-pension private saving for seven OECD countries

people without financial assets to offset the consumption effects of a payroll tax increase than it is for people who have already accumulated substantial savings. 
covering the period from 1971 to 2000 and four other OECD countries for a smaller number of years. ${ }^{14}$

There is wide variation across the countries in both the level of private saving and the relative importance of institutional retirement saving. ${ }^{15}$ Formal retirement saving accounts have modest significance in Japan and Germany, but they are a principal component of private saving in several other countries. Retirement saving is especially important in the United States where it now dominates household saving. In spite of the growth of private retirement saving, particularly during the 1980s, the United States experienced a large and sustained slump in private saving after the mid-1980s. If the faster accumulation of funds in U.S. pension accounts actually represented net new saving, as claimed by Poterba, Venti, and Wise (1998), some unrelated development which caused massive reductions in other forms of household saving must have occurred after 1985. The United States was not alone in experiencing lower private saving. Our tabulations showed a marked decline in private saving rates in most of the OECD countries, with the decline concentrated in non-pension saving. By 2000 non-pension household saving was negative in several of the countries, including the United States.

In the prior paper we obtained a rough measure of the influence of pension and life insurance accumulations on overall private saving by estimating the private-sector equivalent of equation 1:

$$
P S_{i t}=\alpha_{i}+\theta_{i} L I P F_{i t}+\delta_{i} \Delta \mathrm{Y}_{i t}+\lambda t
$$

where

$P S_{\mathrm{it}} \quad=$ Private-sector saving rate of the $i$ th country in year $t$;

$L I P F=$ Net accumulation within life insurance and pension funds, averaged over two years and scaled by national income; and

$\Delta \mathrm{Y} \quad=$ Percentage change in real GDP.

14 The countries with complete data were Australia, Canada, France, Germany, Japan, the United Kingdom, and the United States. Data for a smaller number of years were obtained for Denmark, Italy, the Netherlands, and Sweden.

${ }^{15}$ We usually defined retirement saving as accumulation within life insurance and pension funds. For Canada and the United States pension saving includes accumulations in individual retirement accounts (IRAs). The U.S. data are also detailed enough to permit us to exclude the non-pension fund investments of life insurance companies. 
For technical reasons, the structure of this equation is a bit different from that of equation $1 .{ }^{16}$ Given the difference in specifications, we now expect the coefficient on retirement account saving, $\Theta$, to vary between zero (indicating that added pension saving is completely offset by reductions in other forms of private saving) and unity (indicating no offset). Our estimated model included a trend term and country-specific measures of the unemployment rate and aged dependency ratio to reflect other important influences on private saving. The model also included country fixed effects.

Our basic results suggest the coefficient on life insurance and pension fund saving, $\Theta$, is 0.123. This implies that faster fund accumulation in private pension accounts is almost completely offset by reductions in other forms of private saving. The coefficient was different from unity (indicating no offset) at the 0.01 level of significance, and it was not significantly different from zero (indicating higher pension saving is completely offset). Statistical correction for autocorrelation produced an even smaller estimate of $\Theta$. Thus, the international macroeconomic evidence suggests that increased contributions to formal pension accounts mainly represent a substitute for older forms of saving rather than a net addition to private saving. This inference was not particularly sensitive to the inclusion or exclusion of individual countries in the sample, although it was sensitive to the time period used in the analysis. In the period up through 1990 there is a positive association of between the inflow of funds into retirement accounts and total saving, but this pattern disappears when data from the 1990s are included in the estimation.

The reaction of overall private saving to saving within a voluntary employer-provided pension system does not necessarily provide a reliable guide to the response of household saving to a new system of mandatory private accounts. Our finding nonetheless suggests that the potential for private saving substitution is quite large. Moreover, many social security reform

\footnotetext{
${ }^{16}$ We could not directly estimate the relationship between private retirement saving, on the one hand, and non-retirement private saving, on the other. Our estimates of total private saving and the accumulations in retirement accounts were derived from different (and not necessarily consistent) data sources. The estimate of net accumulation within life insurance and pension funds was derived from national flow-of-funds accounts, while our estimate of total private saving was obtained from the national accounts. Thus, measurement error in the residual - non-retirement saving - is inversely correlated with the error in the estimate of saving within the retirement accounts, biasing the estimate of the substitution between the two forms of saving. The estimation problem is avoided by using the national accounts' measure of total private saving as the dependent variable, but this changes the interpretation of the coefficients.
} 
plans, including those suggested by the President's Commission to Strengthen Social Security, do not envisage mandatory individual retirement accounts. They rely on workers' voluntary decision to participate in a private funded system. It seems plausible to expect that many workers electing to participate will have existing saving accounts that are close substitutes for the new individual retirement accounts. The international evidence suggests that many of the new contributions to reformed pension accounts will be offset by smaller contributions to other kinds of saving accounts.

Implications for reform. Once again we consider the implications of these findings for future saving and national income within a macroeconomic growth model. For purposes of this exercise we consider a reform plan in which workers contribute 2 percent of their Social-Securitycovered earnings to new individual retirement accounts. Funds are accumulated in these accounts until workers reach retirement age, at which point the accumulation is converted into a life annuity that lasts until the worker dies. Survivors of workers who die before the retirement age receive a lump-sum distribution at the time of the worker's death, and we assume that survivors consume the bequest (plus investment earnings on the bequest) over a five-year period. In this paper we disregard year-to-year variability of investment returns. In the baseline forecast workers obtain the average return on bonds, where returns are calculated to be consistent with the Social Security Actuary's forecast of future investment yields on U.S. government bonds. ${ }^{17}$ When new savings accumulated in private pension accounts generates an increase in overall saving, the U.S. capital stock grows larger and the real return falls in comparison with the baseline path. Workers' returns in their investment accounts then reflect the lower predicted path of future returns.

The pensions from the new private accounts will supplement the defined-benefit pensions workers continue to receive under Social Security. It is therefore natural to combine the new accounts program with a reform in Social Security that restores the program's long-term solvency through benefit reductions rather than additional tax increase. We assume benefits are reduced just fast enough to preserve Social Security solvency under a pay-as-you-go rule. In other words,

\footnotetext{
${ }^{17}$ We do not expect that workers would actually invest their retirement savings solely in bonds. However, to make our estimates in Table 2 more comparable to those in Table 1 we assume that the investment portfolios in both sets of simulations are identical. It is convenient to use the portfolio allocation currently followed in the Social Security Trust Fund, which holds all its assets in U.S.
} 
benefits are scaled back in future years by the amount needed so that the trust fund never falls below one year's benefit payments. This will require benefits to be reduced starting shortly after 2030 , with the reduction amounting to 26 percent of currently promised benefits by 2050 . Under our PAYGO assumption, Social Security will not accumulate large future reserves and will not run large annual deficits. Consequently, fluctuations in the Social Security Trust Fund will have almost no effect on public or aggregate saving. All of the extra saving that occurs under this reform will take place in the new private retirement accounts.

Table 2 shows the effects of fund accumulation under this plan using three alternative assumptions about the influence of new pension fund saving on overall private saving. The top panel shows results under the most optimistic assumption regarding feed-back effects on other private saving. Under the assumption that $\Theta=1.0$, an additional dollar accumulated in the private funds adds $\$ 1$ to overall national saving. This estimate naturally produces the largest impacts on future aggregate savings, national income, consumption, and wages. The 2-percent contribution rate to the individual accounts is somewhat smaller than the 2.2-percent increase in OASDI payroll taxes required to bring Social Security into close actuarial balance in the earlier reform plan. This means the potential contribution to saving from fund accumulations in the individual accounts is initially a little smaller than the extra Trust Fund accumulations in the other Social Security reform plan. Nonetheless, when $\Theta=1.0$ the 2-percent contribution rate yields a sizeable increase in annual saving and future national income. By 2025 wages are almost 4 percent higher than they would be in the absence of extra saving, and by 2050 wages are about 6.4 percent higher. Larger national income allows annual consumption to rise above the baseline path by 2020 and to exceed the baseline forecast of consumption by 2.6 percent in 2050 .

These impacts are considerably smaller when $\Theta=0.5$, an estimate that implies one-half of the increase in private-account saving is offset by reduced private saving in other forms. They are smaller still when $\Theta=0.1$, a value which reflects our basic estimate of net private responsiveness to a one-dollar increase in private pension saving. If the latter estimate is accepted, the adoption of a private saving plan, even as a supplement to rather than substitute for PAYGO Social Security, will have very small effects on the future development of national income and consumption.

government bonds. The path of future saving would differ if the investments were partly held in higher yielding securities, such as equities or real estate. 
Many opponents of accumulating a larger reserve in the Social Security system believe such a policy is futile because public officials are likely to use the additional surpluses for larger non-Social-Security spending or smaller non-Social-Security taxes, eliminating the possibility that larger reserves would contribute to higher national saving. Our empirical estimates of the aggregate response of private saving to fund accumulation in private pension plans yield a similar pessimistic conclusion about the effectiveness of private pension accumulation in producing an increase in national saving.

\section{Social Security reform and labor supply}

Social Security reform can change workers' incentives to supply labor as well as to save inside and outside of pension accounts. If the effects on labor supply are large, the future work force and national income can increase as a result of reform. In this part of the paper we focus on incentives to supply labor later in life, particularly past the age of $55 .{ }^{18}$ We assess the empirical evidence of Social Security's impact on older Americans' labor supply and consider how this evidence can be used to evaluate the potential effects of reform on aggregate supply.

Long run trends. Economists studying U.S. retirement patterns agree the introduction and liberalization of Social Security played a significant role in encouraging earlier retirement. There is less agreement on the precise magnitude of this effect. Investigators do not agree on whether the availability of generous Social Security benefits explains most or only a small part of the decline in labor force participation at older ages. Hurd and Boskin (1984) argue that essentially all of the large drop in male participation rates during the late 1960s and early 1970s was due to liberalization of Social Security benefits, while Krueger and Pishke (1992) find that a major reduction in Social Security pensions after 1979 had almost no impact on the trend in male labor force participation. Before considering why estimates of the Social Security impact differ, it is helpful to examine the long-term shift in work at older ages.

The trend toward earlier retirement among American men is clearly apparent in historical statistics on labor force participation over the twentieth century. We can use data from the decennial censuses and the more recent Current Population Surveys (CPS) to track changes in

${ }^{18}$ Social security reform also affects incentives to work at younger ages because it can alter the form and level of contributions for old-age pensions. Moreover, labor supply at ages below 65 is affected by the generosity of and eligibility rules for Social Security disability insurance, a program which is closely coordinated with Social Security old-age pensions. Potential effects of Social Security reform on work effort before 55 will be disregarded in the remainder of this paper. 
participation rates. Statistics for all years show a strong pattern of labor market withdrawal as men grow older. The crucial difference between earlier and later years in the century is that in later years the fall-off in labor force participation begins at a younger age and proceeds at a faster pace.

The decline in male participation was neither smooth nor uniform over the century. The top panel of Figure 1 shows percentage-rate declines in male labor force participation in three different periods: 1910-1940, 1940-1970, and 1970-2002. Between 1910 and 1940, for example, the participation rate of 74-year-old men fell 16 percentage points to 31 percent, and in the next 30 years it fell an additional 13 points. The biggest absolute and proportionate declines in participation occurred among men past the age of 64. In 2002, for example, the participation rate among 72-year-olds was only one third the equivalent rate in 1910. The time profile of the fall-off in participation rates is shown in the top panel of figure 1. Between 1910 and 1940, the reductions in participation rates were substantial only for men aged 64 and over. The drop accelerated between 1940 and 1970, but still only for workers beyond age 61. After 1970, the declines were no longer limited to the oldest workers, bigger declines occurred among men younger than 62. Since the mid-1980s, participation rates among men older than 62 have stabilized and even begun to climb slowly.

The story for older American women is different. We lack information on women's participation rates before 1940. Older women's participation rates in the post-World-War-II era have reflected two partially offsetting phenomena - the early retirement trend among career workers and the increasing labor force participation of married women. As a result of the latter, the participation rates of older women did not exhibit the dramatic post-war declines seen among men. Instead, as shown in lower panel of Figure 1, age-specific labor force participation rates generally increased among women. Between 1940 and 2002, the female participation rate rose 50 percentage points at age 55, 36 points at age 60,13 points at age 65 , and 7 points at age 70 .

Even though long-term trends in older women's participation differ enormously from those among men, there is a striking similarity in the age pattern of male and female labor force withdrawal. The similarity can be seen when we calculate withdrawal rates at successive ages for a particular birth cohort. Suppose that the percentage of people in a birth cohort who are in the labor force between ages 50 and 54 is used to gauge the fraction of the cohort that is classified as "full career workers." Among men born in 1913, for example, the labor force 
participation rate when the cohort was between 50 and 54 averaged 95 percent. By the time men in this cohort attained age 62 (in 1975), their participation rate had fallen to 68 percent, or 72 percent of the participation rate when the cohort was between ages 50 and 54 . When men in the cohort attained age 70 (in 1983), their participation rate had fallen to 20 percent, or just 21 percent of the participation rate when this cohort was 50-54 years old. Among women born in the same year, participation rates at successive ages are much lower than those of men, but the percentage of 50-54 year-old participants who withdraw from the labor force at successive ages after 54 is very similar to the percentage withdrawing among men. Furthermore, while recent cohorts of women had much higher participation rates when they reached ages 50-54 than women in earlier cohorts, women in each successive cohort had labor force withdrawal patterns that were generally similar to those of men born in the same year.

Information from Current Population Survey (CPS) files covering 1962-2002 permit us to make estimates of labor force participation at older ages for cohorts born between 1906 and the early 1930s. The top panel of Figure 2 shows the pattern of labor force engagement, measured as a percent of the cohort's age 50-54 participation rate, for cohorts born between 1906 and 1930. These cohorts attained Social Security's normal retirement age (65) between 1971 and 1995 when the program was essentially mature. Note that when the age-specific labor force engagement rate is measured as a proportion of the cohort's participation rate between ages 50 and 54 there is very little difference in withdrawal patterns between men and women. The average difference in engagement rates at successive ages is just 0.4 percentage points. The largest gap, which occurs at ages 56 and 71 , is 2.4 percentage points.

The information in the top panel of Figure 2 can also be used to calculate the percentage of age 50-54 labor force participants who withdraw from the work force at each successive age. These tabulations are displayed in the bottom panel of Figure 2 for men and women born between 1906 and 1930. Among men and women reaching 65 over the past three decades, labor market withdrawal has tended to cluster at two ages, 62 and 65. These ages are significant in the Social Security program. Age 62 is the youngest age at which workers can claim a reduced oldage pension, and age 65 was the normal retirement age - the earliest age at which workers could claim a full pension. The clustering of retirements at ages 62 and 65 is one piece of evidence suggesting that Social Security affects the timing of labor force withdrawal. The evidence is especially persuasive in the case of men. Among men who reached age 62 before 1960 there is 
no evidence showing that retirements were especially common at age 62. After 1961, when early retirement benefits first became available for 62-64 year-old men, labor force withdrawal at age 62 became progressively more common (Burtless and Moffitt, 1986, and Burtless, 1999). For men and women reaching their 60s since 1980, age 62 is by far the most common age of retirement.

Because detailed labor force participation data are available for only a handful of years before 1962, it is harder to assess exact retirement patterns for cohorts born before 1906. Using data from the Current Population Survey, the Bureau of Labor Statistics has calculated participation rates for multi-year age groups starting in 1957. We can supplement these data with labor force tabulations of the decennial census for two earlier years, 1940 and 1950. These data allow us to calculate the proportion of labor force participants active between ages 50 and 54 who remain active at later ages. The calculations can be performed using contemporaneous estimates of the labor force participation rate of 50-54 year-olds. Figure 3 shows these calculations for women. Each line has a straightforward interpretation. The top line shows the trend in relative participation rates of 55-59 year-old women. In 1940 women in this age group had a participation rate that was 88 percent of the participation rate of women who were 50-54 years old. Although this ratio fluctuated over the next four decades, it declined after the mid1960s. A similar decline is apparent after the late 1960s for women 60-61 years old and 62-64 years old. The participation ratio of women between 65 and 69 and between 70 and 74 fell with very little interruption from 1940 through the mid-1980s. The chart shows a clear pattern of faster relative decline among women 62 and older compared with those aged 61 and younger. As noted above, the earliest age of eligibility for Social Security old-age pensions is 62 . The availability of benefits at age 62 probably helps explain the faster rate of decline in labor force participation for women older than that age.

Similar calculations for men are displayed in Figure 4. These statistics, too, show a clear pattern of faster proportional declines in labor force participation after the age of 62 . Whereas the relative participation rate of 60-61 year-olds fell from 90 percent of the 50-54 year-old rate in 1940 to about 78 percent of the 50-54 year-old rate in 1990, relative participation in the 62-64 year-old group fell from 85 percent to 52 percent over the same period. Participation rate declines among 65-69 year-old and 70-74 year-old men were also considerably bigger on a proportionate basis than the declines among men between 55 and 61. Since Social Security old- 
age benefits are available to men 62 and older, but are not available to men between 55 and 61, it seems likely that Social Security retirement benefits can help explain the differential trends.

Retirement incentives in Social Security. Analysts point to four main ways that Social Security affects lifetime labor supply. It changes workers' lifetime wealth. It affects the marginal payoff to work through its influence on the after-tax wage and the accumulation of future retirement credits. It makes unearned income available to workers who retire or become disabled, reducing the need for further employment. Finally, it imposes an extra tax on the earned income of many people who collect pensions. The Social Security payroll tax, benefit formula, and eligibility rules have been modified over time, altering the work incentives faced by successive generations of workers and retirees.

For most workers who reached retirement age between the 1940s and 1980s, Social Security provided a sizeable increase in lifetime wealth. Because benefits are financed on a PAYGO basis, early contributors to the program did not have to pay high taxes. When they retired they received more generous Social Security pensions than they could have financed out of their payroll taxes and the investment income earned on their contributions. Many people probably responded to the extra wealth by increasing their consumption, including their consumption of retirement leisure. Workers retiring in the past decade have received much smaller windfalls from Social Security, and people who will retire in the future cannot realistically expect any windfalls at all. If the system is reformed, future retirees may actually suffer large losses in lifetime wealth.

Besides affecting retirees' lifetime wealth, Social Security also changes the marginal financial attractiveness of remaining at work. Insured workers can choose to collect Social Security starting at age 62. The effect of Social Security on retirement behavior before age 62 depends on the Social Security tax and on the benefit formula that links monthly pensions to a worker's past covered earnings. For a worker who is less than 62 years old Social Security affects the marginal return from employment by reducing net current pay by about 12 percent and increasing the present value of future Social Security pensions. Whether this increases or reduces the willingness of a worker to continue working depends on the exact amount of the future pension increase (which depends on the worker's expected longevity) and on the worker's attitude toward the relative value of current versus future income and the attractiveness of immediate retirement. 
Starting at age 62 Social Security has a different kind of effect on the retirement decision. When a worker delays claiming retirement benefits by working another year after the earliest age of eligibility, two things happen. The worker passes up an immediate opportunity to collect a Social Security check. On the other hand, future retirement benefits will be higher because average lifetime earnings are recalculated and because the monthly pension check is increased for every month of delay in claiming benefits. Between the ages of 62 and 64 the Social Security formula offers average workers a fair compensation for giving up a year's benefits. Note, however, that a benefit formula that is age-neutral for the average worker can still provide strong financial incentives to retire for workers who have below-average life expectancy. These workers may not expect to live long enough for the future benefit increase to make up for the benefits given up by delaying retirement for one more year. After age 65 Social Security has historically been much less generous toward delayed retirement. Postponement of retirement after that age is not fairly compensated by increases in the monthly pension. In essence, the Social Security formula forces workers who delay retirement after 65 to accept a cut in the lifetime value of their Social Security payments. This is a clear inducement to retire no later than age 65 .

The Social Security formula and eligibility rules have been changed in a number of ways that affect the attractiveness of retirement. Until 1956 workers had to wait until they were 65 to claim a Social Security old-age pension. In that year Congress permitted women reaching age 62 to claim an actuarially reduced pension. Five years later this reform was extended to men. In the early 1970s Congress modified the adjustment in benefits for workers who delayed claiming benefits past age 65. At first the delayed retirement credit was very small, just 1 percent for every year a worker delayed collecting pensions past 65. Starting in 1983 Congress began to phase in a gradual rise in the delayed retirement credit. so that workers who postpone receiving a Social Security pension after the normal retirement age will soon be fairly compensated for the delay. A third important change was also enacted in 1983. For the first time Congress scheduled an increase in the normal retirement age, raising the earliest age when workers can claim an unreduced pension from 65 to 67 . Workers can still claim an early retirement pension at age 62 , but the benefit at that age will gradually fall to just 70 percent of full Social Security pension. For workers who reached age 62 before 2000, the early retirement benefit was 80 percent of a full pension. Finally, some people receiving Social Security benefits were deterred from working by 
the retirement earnings test, which imposes heavy (though temporary) pension reductions on workers who receive labor earnings above a specified level. Congress has gradually raised the earnings limit and reduced the income penalty associated with the retirement earnings test. In 2000 the earnings test was eliminated for pensioners who have attained the normal retirement age.

One measure of the generosity of Social Security is the replacement rate it provides workers who retire at some standard age, say 65 . Figure 5 shows the net replacement rate provided to new retirees who began collecting old-age pensions between 1950 and 2001. The net replacement rate is the ratio of average Social Security benefits and the average after-tax wage. To approximate the benefit workers would receive if they retired at a standard age, we took the Social Security Administration's estimate of the average "Primary Insurance Amount" (or PIA) of workers filing new claims for old-age benefits. ${ }^{19}$ The PIA is simply the full Social Security pension for a single worker who claims benefits at the normal retirement age, or age 65 . Actual benefits are lower than this for workers retiring before age 65; they are higher for workers retiring later. The Social Security Administration provides estimates of the average PIA separately for men and women who claim retired worker benefits.

We approximated the average wage using two methods. The Census Bureau publishes estimates of median annual earnings separately for men and women. One problem with this estimate is that it includes the very low earnings of a varying number of teenagers. For years after 1966 we can use income reports in the March Current Population Survey to calculate average earnings of workers who are closer to retirement. In Figure 5 we use average earnings of employed 55-59 year-olds, separately for both men and women, to approximate the earnings that older workers of each sex would have to give up if they left employment. Before calculating the ratio of benefits to earnings we subtracted payroll tax withholdings from the worker's wage. The worker's portion of the payroll tax increased from 1 percent to 7.65 percent of wages between 1950 and 2001, so the tax has a noticeable effect on the replacement rate.

Using either measure of net wages, the replacement has trended upward over time for both men and women. Not surprisingly, the replacement rate is lower if earnings among 55-59

19 Because benefit levels were often increased during the middle of a calendar year, we always used average PIA amounts for the part of the year that includes December. For workers who retired earlier in the year, the December pension amount would reflect all cost-of-living adjustments applied up through the end of the year. 
year-olds are used as a benchmark for potential earnings. Median earnings of all active workers are lower than the mean earnings of 55-59 year-olds, so the replacement is lower when the latter benchmark is used. Until recently, women's replacement rates were higher than those of men, regardless of the wage benchmark used. This is a logical result of the Social Security benefit formula, which offers higher replacement rates to workers with lower lifetime earnings. Because women earn lower average wages than men, they historically benefited from the redistributive tilt in the formula when claiming retired worker pensions. Beginning in the early $1980 \mathrm{~s}$, however, the replacement rate of newly retired male and female workers has been more nearly equal, a consequence of much faster wage growth among women than among men. If we use mean earnings of 55-59 year-olds as a benchmark for potential earnings, the average male and female retired-worker replacement rate has been very similar since 1983 .

The chart shows a sharp increase in pension replacement rates for men at the beginning of the 1950s, and again during the 1970s. These increases are linked to sharp improvements in pensions enacted by Congress in 1950, 1969, 1972, and 1974. The male replacement rate trended slowly upward after the mid-1980s, even though benefit generosity was curtailed by amendments passed in 1977 and 1983. Part of the explanation is the poor relative performance of male earnings, especially among men earning average and below-average wages. A growing percentage of male retirees thus benefited from the redistributive tilt of the pension formula, improving the ratio of new pensions to current male wages.

Surprisingly, the statistics show a decline after 1981 in replacement rates provided to newly retired women. Part of the drop is due to the 1977 amendments, which cut benefit growth among workers who retire after the early entitlement age (Myers et al., 1988). It is puzzling, however, that the impact of this formula change on women's retirement benefits was so much bigger than the impact on men's. One factor contributing to lower replacement rates was the rise in women's relative earnings. Median female earnings increased 209 percent between 1980 and 2001 whereas median male earnings rose only 123 percent.

The impact of Social Security on retirement is obviously affected by the proportion of workers who qualify for benefits. Eligibility for Social Security rose rapidly in the 1950s and early 1960s as a result of expansions in the percentage of workers covered by the program. These expansions are reflected in sizeable increases in the percentage of men and women who were eligible for or actually receiving a Social Security retired-worker benefit when they reached 
ages 65-69 (see Figure 6). The statistics displayed in Figure 6 do not reflect benefits paid to people who qualify for Social Security solely as dependents or surviving widows of a covered worker. Many women are eligible for dependent benefits even though they may not have accumulated enough earnings credits to become eligible for retired-worker pensions based on their own employment record. The availability of dependents' and widows' benefits also affects our interpretation of replacement rates available to women. Many women are entitled to a supplement to their own retired-worker pension as a result of their eligibility for a dependent spouse or widow's pension. If this supplement is added to the worker's retired-worker benefit, the Social Security replacement rate for newly retired women could be substantially higher than implied in Figure 6. The importance of dependent benefits has declined, however, as women's lifetime earnings have increased. A smaller percentage of newly retired women receive a supplement to their own retired-worker benefit as a result of their eligibility for a dependent spouse benefit based on a husband's earnings record. The spousal benefit is quite unimportant for retired men.

The above description of the financial incentives in Social Security sheds some light on the retirement trends discussed earlier. Social security is now the main source of cash income of households headed by someone 65 or older. The program provides 38 percent of the total cash income received by the aged. Among aged households in the bottom 60 percent of the elderly income distribution, Social Security provides two-thirds or more of cash income (U.S. Social Security Administration, 2000, pp. 15-16). Until 1941, Social Security provided no income at all to the aged. According to Social Security Administration calculations, the program now replaces about 42 percent of the final wage earned by full-career single workers who earn the average wage in every year of their work life and claim a pension at the normal retirement age. If a worker has a non-working dependent spouse, the benefit replaces 63 percent of the worker's final wage (U.S. House of Representatives, Committee on Ways and Means, 2000, Table 1-17). Benefits are clearly large enough so they can be economically significant in influencing the choice of retirement age.

Previous estimates of Social Security effects. The number of studies attempting to measure the effect of Social Security on retirement is now quite large. Good surveys of the literature have been prepared by Quinn et al. (1990), Hurd (1990), Lumsdaine and Mitchell (1999), and Krueger and Meyer (2002). Our reading of this literature is that, with a few notable 
exceptions, most careful studies find rather small effects of Social Security on older workers' labor force participation. That is, the effects appear to be small compared with the large historical changes in U.S. participation rates documented in Figures 1, 3, and 4.

Krueger and Meyer (2002) distinguish between two broad approaches to estimation. One class of study relies on time series changes in Social Security incentives to identify the impact of incentives on some measure of aggregate labor supply. A second relies on differences among a cross-section of workers at a particular point in time to disentangle the influence of detailed program incentives on individual workers. A few studies use the combination of both timeseries and cross-section variation to determine the effects of Social Security incentives based on longitudinal data for a representative sample of workers. To this list we should also add crossnational studies of the effects of different retirement systems on aggregate supply.

The aggregate time series evidence for the United States seems to suggest a large effect of the program. As we have seen, participation rates of full-career workers fell after Social Security became an important source of retirement income. Participation rates fell particularly rapidly during the 1970s when benefits were greatly liberalized. Furthermore, participation rates past age 61 and especially past 65 began to rise after the mid-1980s when work-discouraging features of the program were removed or modified.

There are two problems with this kind of evidence. First, participation rates of older men were declining even before Social Security benefits began to be paid, suggesting that other factors besides Social Security lie behind at least some of the trend toward earlier retirement (see the top panel in Figure 1). Second, if workers were induced to earlier retirement by windfall increases in wealth provided by Social Security, it is surprising that so much of the decline in labor force participation occurred after 1970. As noted by Robert Moffitt (1987), the unexpected windfall gains in lifetime wealth produced by Social Security were mainly concentrated in the 1950s, not in the 1970s. This implies that the largest labor supply effects of the program should also have been concentrated in the 1950s and early 1960s, and Moffitt finds little evidence for this in the data.

The second kind of analysis focuses on differences between individual workers to identify the effects of detailed Social Security incentives on labor supply. An advantage of this approach is that incentives can be accurately measured. Another is that other influences on labor supply, including workers' health and other pension entitlements, can also be taken into account. 
These studies typically analyze the cross-sectional distribution of retirements within a group of workers who reach old age around the same time. The behavior of workers with a large amount of Social Security or pension wealth is compared with that of workers with less wealth. The analyst takes account of differences in the rate at which workers can accumulate additional Social Security and private pension wealth and can earn additional wages.

Most studies of this type find that even big changes in Social Security cause only modest changes in participation rates. Burtless and Moffitt (1985) predict, for example, that raising the normal retirement age in Social Security from 65 to 68 would add only a little more than 4 months to the full-time working careers of men who are not disabled. In a recent assessment of the impact of Social Security changes on male labor force participation in the 1970s and 1980s, Anderson, Gustman, and Steinmeier (1999) use cross-sectional evidence from the Retirement History Survey to estimate a sophisticated and forward-looking retirement model based on the experiences of 3,300 men who retired in the late 1960s and 1970s. They obtain behavioral estimates that seem sensible and very precisely estimated. When they use these estimates to simulate the aggregate response to the Social Security changes over the 1970s and 1980s they find only small predicted changes in male participation rates. Between 1969 and 1989, male participation rates fell 14 percentage points at age 60,25 points at age 62, and 17 points at age 65. Changing Social Security incentives can explain only one-seventh of the decline at ages 60 and 62 and none of the participation-rate decline at age 65. In fact, the authors find that Social Security reforms should have induced a small increase in male participation rates at age 65 (Anderson et al., 1999, p. 777).

Another way to analyze the influence of Social Security is to examine behavioral differences among people who face different incentives because the program has been altered in an unanticipated way. In 1969 and again in 1972 Social Security benefits were increased much faster relative to wages than at any time in the recent past. By 1973 benefits were 20 percent higher in inflation-adjusted terms than would have been the case if pensions had grown with wages as they did during the 1950s and 1960s (see Figure 5). In 1977 Congress passed amendments to the Social Security Act that sharply reduced benefits to workers born in 1917 and later years (the "notch" babies) in comparison with benefits payable to workers born before 1917. Burtless (1986) examined the first episode, and Krueger and Pishke (1992) examined the second. In the period analyzed by Burtless, older workers in his sample planned their 
retirements when Social Security was comparatively less generous; younger workers planned their retirements when Social Security benefits were 20 percent higher. Krueger and Pischke analyzed a period in which younger workers received significantly less generous pensions than those available to older workers. Both studies reached an identical conclusion. Major changes in Social Security generosity produced small effects on retirement behavior and labor force participation. Burtless estimated, for example, that the 20-percent benefit hike between 1969 and 1973 caused only a 2-month reduction in the work career of men who were fully covered by the more generous formula. This was equivalent to a reduction in the labor force participation rates of 62-year-old and 65-year-old men of less than 2 percentage points. The effects of the 1977 amendments found by Krueger and Pischke were even smaller. Even if their largest estimated effects are accepted, less than one-sixth of the drop in labor force participation during the 1970s can be explained by changes in Social Security.

Another kind of evidence is based on comparisons of retirement patterns in different countries where pension systems are very different. Gruber and Wise (1999) undertook one of the most meticulous studies of this type. It reaches a very different conclusion from the one based on cross-sectional and panel data from the United States. Gruber and Wise and their expert collaborators examined pension systems and retirement incentives in 11 industrialized countries. Some of these countries allow workers to begin drawing public pensions at age 60 or even earlier, while others do not make old-age benefits available until later. There is also wide variation in the treatment of labor earnings once workers reach the pensionable age. Some countries, like the United States, provide relatively modest public pensions and do not penalize workers for delaying their retirement beyond the early and normal pensionable ages. Other countries, like France and the Netherlands, provide much more generous pensions and impose heavy financial penalties on workers who remain employed after the pensionable age. The Gruber and Wise study reports a strong correlation between national retirement patterns and the labor supply incentives that are embodied in national pension systems. Countries with modest pensions and generous treatment of earned income after the pensionable age have high rates of participation among people between 55 and 70 years old. Countries offering very generous pensions and imposing heavy penalties on earnings after the pensionable age have much lower participation rates at older ages. 
These findings imply that the trend in labor force participation at older ages was decisively influenced by incentives in national retirement systems. While all the rich countries have seen major declines in older males' activity rates, the extent of decline has been affected by the details of the national pension system. Compared with the cross-sectional and panel data studies discussed above, the Gruber and Wise (1999) analysis implies a much bigger impact of the Social Security system on activity rates at older ages.

It is conceivable that the cross-national comparison is uncovering a long-run effect of generous pensions that is impossible to measure in microeconomic studies of people who retire within a few years of one another. In particular, more generous income support programs for the retired may influence the trend in average workers' preferences regarding the desirability of work in old age. More generous pensions encourage earlier retirements among a few workers, and this development may then affect opinions regarding retirement among a much wider class of people. Longer retirement becomes an acceptable, highly desired part of a typical worker's life. This impact of Social Security and pensions is hard to detect in cross-sectional and panel studies of the kind discussed above. Those studies attempt to find a correlation between workers' choice of retirement age and the financial incentives (or change in incentives) that might motivate workers to retire at one age rather than another. If the average worker's preferences for retirement versus consumption have gradually changed as a result of a socialsecurity-induced shift in preferences, this shift would be missed in cross-sectional and panel studies, although it might be detectable in a cross-national study where the analyst can see the long-term impact of stable differences in the retirement system.

Some evidence suggests that behavior is slow to change in the face of changing financial incentives. It took a number of years after the introduction of early Social Security pensions before retirement at age 62 became common. The financial incentives that eventually induced men to retire at age 62 were presumably present from the first day early pensions were offered in 1961. It was only in the late 1960s, however, that a sharp fall-off in labor force participation at age 62 became noticeable. By the late 1970s, the fall-off in participation was greater at age 62 than at age 65 . This evidence may imply either that workers are slow to recognize the financial implications of a complicated innovation or that their preferences are formed, in part, by indirect effects of the financial incentives facing them. 
Simulating labor force response to reform. How big was Social Security's impact on past labor force participation? Even though conflicting evidence does not provide a definitive answer to the question, it is possible to use some of the evidence to develop reasonable estimates of the range of potential effects of future reform. As noted above, Anderson et al. (1999) used estimates based on a cross-sectional empirical study to infer the effects of the reforms implemented in the 1970s and 1980s. Since their estimates were based on a statistical methodology that typically produces small predictions of Social Security's effects, it is helpful to contrast them with an alternative technique that suggests a larger impact. This approach can provide an upper-bound - and probably unrealistically high - estimate of the potential effect of reform.

We first estimate a time-series model in which aggregate labor supply in old age is solely determined by Social Security incentives. This approach probably overstates the impact of Social Security, because it disregards other influences which have the same general trend as Social Security benefits. Some of these also encouraged earlier retirement. For example, the private, non-Social-Security retirement system has grown larger and provided more generous retirement incentives to recent generations of workers. The impact of this expansion will be partly attributed to Social Security in the approach we follow. ${ }^{20}$

In the simplest model of Social Security effects, participation rates at older ages are determined by the net replacement rate provided by the program and by the earliest age at which benefits can be claimed. Higher replacement rates and earlier benefit entitlement should encourage earlier retirement and induce lower labor force participation. Our preferred measure of labor force participation for a given age group measures the group's participation relative to the participation rate of a group that is presumed to be largely unaffected by Social Security oldage pensions. The oldest age group likely to be unaffected by the retirement incentives of social

${ }^{20}$ It is conceivable, of course, that the creation and expansion of Social Security encouraged the development and expansion of private retirement pensions. In the absence of Social Security, employers and workers might not have moved to create or enlarge a voluntary fringe benefit that only makes sense if a large number of workers can afford to retire. If this hypothesis is correct, the post-war decline in older workers' participation rates should be attributed to Social Security rather than to private pensions, because the expansion of the private pension system was itself a by-product of Social Security and its liberalization. 
security consists of people who are between 50 and 54 years old. ${ }^{21}$ Thus, we measure participation rates relative to the participation rate of 50-54 year-olds. Because of limitations in the data before 1976, our analysis focuses on relative male and female participation rates in four main age groups (55-59, 60-64, 65-69, and 70-74) and two smaller subgroups (60-61 year-olds and 62-64 year-olds). We take two approaches to measuring a group's relative participation rate in a given year. Under one approach, the relative participation rate of, say, 55-59 year-olds is measured relative to the 50-54 year-old participation rate in the same year, $L_{55-59, t} / L_{50-54, t}$. Under the alternative, it is measured relative to the 50-54 year-old participation rate exactly five years earlier, $L_{55-59, t} / L_{50-54, t-5}$. The short-hand label for latter concept is "lagged relative participation." Although in many ways the second variable is the preferred way to measure relative participation rates, limitations in the Census and CPS data mean it cannot be calculated for as many years.

Our measure of the net replacement rate has already been described. For a given year it is the average PIA for workers claiming a new retired-worker benefit divided by median earnings, with the ratio measured as a percent. Our measure of the duration or wait until entitlement for a retired-worker benefit is the difference between the average age in the group and the earliest entitlement age for retirement benefits, measured in years. For workers who are younger than the earliest entitlement age, this number is positive; for workers older than the earliest entitlement age, it is negative. The only time-series variation in the variable occurs when the early entitlement age changes (in 1956 for women and in 1961 for men). The statistical identification of effect of duration-to-benefit-entitlement is, therefore, very fragile. Data are available to estimate the model separately for men and women. Because we do not have continuous data on the dependent variable, it is impossible to obtain good auto-correlation corrected estimates of the coefficients.

Coefficient estimates for the six age groups are displayed in Table 3, with results for men in the top panel and for women in the lower panel. The model is more successful in explaining the trend in relative participation among men. The effect of the replacement rate on relative

${ }^{21}$ The labor force participation of 50-54 year olds will be affected by the disincentive of the wage tax and the gain of qualifying for a larger pension. In that respect, our assumption is an oversimplification. However, the stability of the male participation rate over the past century suggests that the effects are small. For women, the spousal benefit of Social Security should have discouraged 
male participation is always found to have the correct sign and is almost always very precisely estimated. Except in the oldest age groups there is also close agreement on the estimated effect of the replacement rate regardless of whether the relative participation rate is measured with the contemporaneous or lagged value of the age 50-54 participation rate. The difference in estimated coefficients between the two sets of regressions is partly due to differences in the estimation period. Particularly in the older age groups, the estimates based on the lagged value of the 50-54 year-old participation rate cover a smaller number of years. A smaller proportion of the observations relate to the 1950 s, when replacement rates were low.

The estimated effects of the time-to-benefit-entitlement usually have the correct sign but they are much less precisely estimated than the effects of the replacement rate. Moreover, the estimated effects of the time-to-benefit-entitlement are sensitive to the definition of the dependent variable. This sensitivity should not be surprising in view of the fact that there is no variation in the time-to-benefit-entitlement after the early 1960s. Thus, the estimate of the coefficient will be quite sensitive to number and character of observations included for the 1950s. The pattern of coefficients across age groups makes sense. Men between 62 and 64 years old seem most sensitive to changes in the Social Security replacement rate, while workers under 60 and older than age 70 are less sensitive.

The model does not do a good job explaining variation in relative participation rates of older women. Coefficients on the net replacement rate implausibly suggest that more generous retired-worker benefits induce women older than 55 to increase their participation rates relative to those of 50-54 year-olds, though many of the estimates are not significantly different from zero. The implausible estimate of the effect of Social Security replacement rates may be the result of our poor measure of women's replacement rates. We have a good measure of the age65 benefits women can receive if their pensions consisted solely of retired-worker benefits calculated on their own earnings records. Many retired women receive higher benefits, however, because their own retired-worker pensions are supplemented by a dependent spouse benefit or because they receive a widow's pension instead of their own retired-worker benefit. Given the limitations of the data, it may not be possible to estimate the effects of the Social Security replacement rate on women's participation at the aggregate level.

labor force participation, and we attribute the observed rise for younger persons to other economic and social factors. 
On the other hand, the estimated effects of time-to-benefit-entitlement have the correct sign and are often significantly different from zero. However, these coefficients are very sensitive to the definition of the dependent variable. Because early retirement benefits were offered to women five years earlier than they were to men, there are even fewer available observations to statistically identify the effect of this variable. In fact, when the dependent variable is defined using the lagged participation rate of 50-54 year-olds, it is not possible to identify the effect of time-to-benefit-entitlement on women who are 65-69 years old. For women in this age group there are no observations which represent the situation of women who were not entitled to benefits at age 62 .

Effects of reform. The coefficient estimates in Table 3 can be used to predict the future effects of Social Security reform. We focus on reforms that reduce the age-65 replacement rate or increase the early entitlement age. As noted above, our predictions provide an upper bound estimate of labor supply response because they are based on a model which assumes all past changes in participation rates were the result of changes in Social Security generosity. We consider three reforms, two that affect the age- 65 replacement rate offered by Social Security and a third that changes both the replacement rate and the early entitlement age. The first reform is an increase in the normal retirement age (NRA) from 65 to 67, a reform passed by Congress in 1983 that is scheduled to take place for workers attaining age 65 between 2003 and 2025. This reform will reduce replacement rates payable to workers claiming age- 65 benefits by 6.7 percent in 2010 and by 13.3 percent in 2030 . The second reform accelerates the increase in the normal retirement age and ultimately increases the normal retirement age to 70 rather than 67 . This reform reduces age- 65 replacement rates by 10.6 percent in 2010 , by 21.7 percent in 2020 , and by 33.3 percent in 2032 and later years. ${ }^{22}$ The third reform we consider increases the normal retirement age from 65 to 67, as scheduled under current law, and increases the early entitlement age from 62 to 64 . This reform has the same impact on replacement rates as the first reform, but it also increases the wait for retired-worker benefits by two years.

${ }^{22}$ We increase the NRA by 2 months every calendar year starting with workers attaining age 65 in 2003. The workers who attain age 65 in 2032 must thus wait to age 70 to claim an unreduced pension. Under the Social Security Amendments of 1983, Congress raised the NRA in two-month annual increments to age 66 for workers reaching age 65 between 2003 and 2008 and to age 67 for workers reaching age 65 between 2020 and 2025 . 
The simulated response to these reforms is displayed in Table 4. The top panel shows results for men; the bottom panel, results for women. The predictions are based on coefficient estimates obtained when the dependent variable was measured relative to the contemporaneous participation rate of the 50-54 year-old age group. The first four columns in Table 4 show predicted labor force changes within the four main age groups we have been examining. To calculate the overall change in the labor force for people between 55 and 74 in column 5, we constructed a baseline based on unpublished population and labor force projections of the Social Security Actuary for the 2003 OASDI Trustees' Report. These predictions are also used to calculate the aggregate change in the labor force of men and women age 16 and older in column $6 .^{23}$

The pattern of results for men seems plausible. We estimate that the increase in the normal retirement age from 65 to 67 will increase the labor force by 2 percent among 55-59 year-olds and by $9-11$ percent among men 60 and older. If the normal retirement age is increased to age 70 , the ultimate effects are about $2-1 / 2$ times larger than an increase in the retirement age to 67. Even though this reform is predicted to increase the size of the 55-74 yearold work force by 15 percent, the impact on the male labor force age 16 and older is less than 3 percent. If an increase in the normal retirement age to 67 is combined with an increase in the early entitlement age to 64 , the 55-74 year-old male labor force would increase about 10 percent, but this would add less than 2 percent to the total U.S. work force.

For purposes of comparison, we also calculated the change in labor force that would occur if relative participation rates within older age groups returned to their 1950 ratios. To perform this calculation, we assume that relative participation rates gradually rise from the observed ratios in 2002 to the 1950 ratios by 2040 . This assumption implies that the relative participation rate of men between 65 and 74 will double by 2040. Thus, our coefficient estimates suggest that the increase in the NRA to 67 will ultimately eliminate one-tenth of the decline in participation that has occurred among men over 65 and about one-third of the decline that has

${ }^{23}$ The Social Security Actuary's 2003 forecast is based on the assumption that future participation rates among people 55-74 will gradually rise relative to participation rates among people 50-54 years old. Because we want to compare future labor supply to a baseline path in which relative participation rates do not change, we have modified this feature of the Actuary's forecast. In our baseline simulation, we assume that future participation rates of men and women between 55 and 74 do not change relative to those of 50-54 year-olds. This reduces slightly the Actuary's forecast of aggregate labor supply. Participation rates of men and women under age 55 follow the exact path predicted by the Actuary. 
occurred among men 55-64. An increase in the retirement age to 70 would eliminate about onequarter of the decline among 65-74 year-olds and two-thirds of the decline among 55-64 yearolds.

The predictions for women are less plausible. The coefficients reported in Table 3 suggest the reductions in Social Security replacement rates that would accompany an increase in the NRA will modestly reduce older women's participation rates. On the other hand, the increase in the early entitlement age for retired-worker benefits is predicted to induce substantial increases in participation for women over age 60, especially among women between 65 and 69 . The predictions imply that the increase in participation following an increase in the early entitlement age would ultimately eliminate almost one-half of the relative decline in participation that has occurred among women between 65 and 69 and two-thirds of the decline that has occurred among women between 70-74 since 1950. However, the predicted 11 percent increase in the female labor force between 55 and 74 translates into an increase in the total female workforce of less than 2 percent.

An alternative way to predict the future labor supply of older women is to assume that participation rate changes will mirror the more plausible response patterns we estimated for men. If lifetime labor supply among women is gradually converging toward the life cycle pattern observed among men, the participation response functions estimated for men may offer a more reliable guide to potential participation changes among women. Under this assumption, the responses in the top panel of Table 4 provide a better forecast of female responses after an increase in the early retirement age or cut in age- 65 benefit levels.

\section{Conclusion}

One justification for reforming Social Security is that reform can improve incentives for saving and labor supply. If valid, this assumption means reforms can increase the future size of the economy and reduce the burden of supporting a bigger elderly population. Proposals to increase advance funding within public or private pensions are often justified by their supposed effects on aggregate saving. In addition, plans to scale back or modify Social Security are sometimes defended because they improve incentives to supply labor at older ages, increasing the earnings that are available to pay for pensions and reducing the income gap that pensions must fill. In this paper we examined some of the empirical evidence supporting the argument that reform can produce an increase in labor supply or saving. We sought to provide upper 
bound estimates of the potential consequences of these responses for aggregate supply. Our analysis focused on three kinds of reform: The accumulation of extra saving in the government within an advance-funded public retirement system; the accumulation of higher saving in private advance-funded pensions; and the postponement of retirement among workers who anticipate smaller pensions.

We find mixed evidence on the ability of governments to increase public saving by accumulating larger reserves in public pension systems. The experience of state-level governments in the United States suggests that faster accumulation of public pension reserves can produce higher government saving on almost a dollar-for-dollar basis. States that accumulate exceptionally large reserves within their pension funds do not act as though the funds are available to finance non-pension state government operations. Nor do states use bigger reserves in their pension funds to provide short-term tax relief to state residents. The crossnational evidence offers a different lesson about the public budget response to pension fund accumulation. This evidence implies that a large part of any accumulation within national social insurance systems is offset for the government sector as a whole by larger budget deficits in other accounts. On average, OECD countries have been able to save only a small part of the extra funds accumulated within their social insurance systems. Between 60 and 100 percent of the saving within pension funds is offset by reductions in government saving elsewhere in the budget.

Obviously the contrasting estimates of public saving responsiveness have very different implications for the desirability of accumulating reserves within a public pension system. Based on state-level evidence, we find that a policy which increases Social Security taxes in anticipation of large future pension costs can significantly increase U.S. national saving and future national output. These estimates imply that future aggregate saving will increase one-third and future national output will increase 9 percent if payroll taxes are increased immediately to bring the Social Security program into close actuarial balance. The effects are only one-tenth as large if we base our predictions on the cross-national experience. Whether the optimistic or pessimistic conclusions should serve as a basis for policy depends crucially on how pension fund accumulation is managed within the government. The contrasting empirical results for U.S. states and OECD nation states can be traced to differences in the governance of the pension 
systems and the degree of effort that is made to separate the pension funding from other budget activities.

When we examined saving responses within the private sector to fluctuations in private insurance and pension fund accumulation we found considerable evidence that pension saving substitutes for other forms of private saving. Past experience with voluntary private pension programs is not directly applicable in the case of reform in which the government scales back Social Security and establishes a new system of mandatory pension accounts. Nonetheless, past experience strongly suggests that asset substitution is a significant problem when workers hold their savings in both pension and non-pension accounts. This kind of substitution can severely limit the effects of larger accumulations in private pension accounts. The net impact of extra private pension accumulations on aggregate private saving may therefore be small.

Finally, our brief review of the empirical evidence on old-age labor supply offered abundant evidence of the existence of an effect of Social Security but only limited evidence that the effect is large. Most good retirement studies based on cross-sectional and panel data suggest the response to Social Security incentives has been small. That is, most analysts find that the likely impact of Social Security is small in comparison with the changes in old-age labor supply that have been observed over the past half century. If the cross-sectional and panel estimates are accepted as valid, the nation can anticipate modest changes in aggregate labor supply from reform in the pension system. In contrast, Gruber and Wise (1999) recently offered estimates based on cross-national comparisons of aggregate labor supply. Their new estimates suggest that the long-run response to pension reform can be much bigger than the responses uncovered in most microeconomic studies.

To provide an upper-bound estimate of the potential effects of Social Security reform on the future U.S. labor supply we estimated a simple model to explain shifts in relative labor force participation rates over the post-war period. Our parsimonious model was intentionally designed to attribute all the long-term decline in old-age participation rates to long-term increases in the Social Security replacement rate and reductions in the early entitlement age for benefits. Using parameter estimates of this model, we predicted the long-run effects of reforms that noticeably reduce Social Security generosity. Predictions based on this model suggest that reducing Social Security benefits by a third might increase labor force participation of 55-74 year-old men by 15 percent. A reform which increases the eligibility age for early Social Security pensions might 
increase female participation in the same age group by 11 or 12 percent. Although these responses seem large, they would add only 2-3 percent to the size of the future U.S. workforce. Moreover, the predictions almost certainly overstate the impact of reform. A more plausible behavioral model would include the effects of rising lifetime wealth and more generous private pensions when measuring the impact of Social Security on old-age labor supply. If the effects of wealth gains and private pension liberalization were taken into account, the estimated effect of Social Security of post-war labor supply would be smaller.

Overall, our findings suggest that the ability of pension reform to expand incentives for saving and labor supply may be less than often assumed. Therefore, efforts to offset the future costs of population aging by increasing the future size of the economy may be difficult to achieve. Efforts to raise retirement saving may be offset by the actions of individuals and their elected officials that reduce other forms of saving. Our evaluation of the research on the effects of Social Security on the labor force participation of older workers also suggests that the effects of reform will be small. 


\section{References}

Aaron, Henry J., Barry P. Bosworth, and Gary Burtless. 1989. Can America Afford to Grow Old? Paying for Social Security (Washington, D.C.: The Brookings Institution).

Anderson, Patricia M., Alan L. Gustman, and Thomas L. Steinmeier. 1999. "Trends in Male Labor Force Participation and Retirement: Some Evidence on the Role of Pensions and Social Security in the 1970s and 1980s." Journal of Labor Economics 17(4): 757-83.

Atkinson, Anthony B. 1987. "Income Maintenance and Social Insurance," in Alan Auerbach and Martin Feldstein (eds.), Handbook of Public Economics, vol. 2 (Amsterdam: North Holland: 779-908).

Attanasio, Orazio P. and Susann Rohwedder. 2003. "Pension Wealth and Household Saving: Evidence From Pension Reforms in the United Kingdom." American Economic Review, 93(5): 1499-1521.

Bailliu, Jeannine, and Helmut Riesen. 2000. "Do Funded Pensions Contribute to Higher Aggregate Saving? A Cross-Country Analysis," in Helmut Riesen (ed.), Pensions, Savings, and Capital Flows: From Aging to Emerging Markets (Cheltenham, U.K.: Edward Elgar: 114-31).

Bosworth, Barry P., and Burtless, Gary. 1997. "Social Security Reform in a Global Context," in Steven A. Sass and Robert K. Triest (eds.), Social Security Reform: Links to Saving, Investment, and Growth. (Boston, MA: Federal Reserve Bank of Boston).

. 2000. "The Effects of Social Security Reform on Saving, Investment, and the Level and Distribution of Worker Well-Being," Working Paper 2000-02. (Chestnut Hill, MA: Boston College Center for Retirement Research).

. 2003. "Pension Reform and Saving," prepared for a conference of the International Forum of the Collaboration Projects held February 17-19, 2003, in Tokyo, Japan.

Bosworth, Barry P., Gary Burtless, and Claudia Sahm. Forthcoming. "Distributional Impact of Social Security Reform," in Paolo Onofri (ed.), The Economics of an Ageing Population: Macroeconomic Issues (Cheltenham, U.K.: Edward Elgar).

Burtless, Gary. 1986. "Social Security, Unanticipated Benefit Increases, and the Timing of Retirement." Review of Economic Studies 53(5):781-805.

. 1999. "An Economic View of Retirement," Henry Aaron, ed., Behavioral Dimensions of Retirement Economics (Washington, D.C.: The Brookings Institution).

Burtless, Gary, and Robert Moffitt. 1985. "The Joint Choice of Retirement Date and PostRetirement Hours of Work." Journal of Labor Economics 3(2): 237-53. 
. 1986. "Social Security, Earnings Tests, and the Age at Retirement." Public

Finance Quarterly 14(1): 3-27.

Congressional Budget Office. 1998. "Social Security and Private Saving: A Review of the Empirical Evidence." Memorandum (Washington D.C: Congressional Budget Office).

Engen, Eric M., William Gale, and John Karl Scholtz. 1996. "The Illusory Effects of Saving Incentives on Saving," Journal of Economic Perspectives, 10 (4):113-38.

Gale, William G. 1998. "The Effects of Pensions on Household Wealth: A Reevaluation of Theory and Evidence," Journal of Political Economy, 106(4): 706-23.

Granville, Brigitte, and Sushanta Mallick. 2002. "Does Capital Market Reform Boost Saving: Evidence From the UK Pension Reform," paper presented at the 2002 T5 Research Conference, Tokyo, Dec 3-4.

Gruber, Jonathan, and David A. Wise. 1999. "Introduction" in Jonathan Gruber and David A. Wise (eds.), Social Security and Retirement Around the World (Chicago: University of Chicago Press).

Gustman, Alan L. and Thoms L. Steinmeier. 1999. "Effects of Pensions on Saving: Analysis With Data From the Health and Retirement Study." Carnegie-Rochester Conference Series on Public Policy, 50: 271-324.

Harris, Jennifer D. 2002. "2001 Survey of State and Local Government Retirement Systems," prepared for the members of the Pension Policy Coordinating Council. http://ppcc.grsnet.com/

Hemming, Richard. 1999. "Should Public Pensions Be Funded." International Social Security Review, 52(2): 3-30.

Hurd, Michael D. 1990. "Research on the Elderly: Economic Status, Retirement, and Consumption and Saving." Journal of Economic Literature 28(2): 565-637.

Hurd, Michael D., and Michael J. Boskin. 1984. ""The Effect of Social Security on Retirement in the Early 1970s." Quarterly Journal of Economics 99(4): 767-90.

Krueger, Alan, and Bruce D. Meyer. 2002. "Labor Supply Effects of Social Insurance.” NBER Working Paper No. 9014 (Cambridge, MA: National Bureau of Economic Research).

Krueger, Alan, and Jorn-Steffen Pischke. 1992. "The Effect of Social Security on Labor Supply: A Cohort Analysis of the Notch Generation." Journal of Labor Economics 19(4): 412-37. 
Lumsdaine, Robin, and Olivia S. Mitchell. 1999. "New Developments in the Economics of Retirement," Orley Ashenfelter and David Card (eds.), Handbook of Labor Economics, Volume 3. (Amsterdam: North Holland, 3261-3308).

Moffitt, Robert A. 1987. "Life-Cycle Labor Supply and Social Security: A Time-Series Analysis," in Gary Burtless (ed.), Work, Health, and Income among the Elderly (Washington, DC: Brookings).

Munnell, Alicia, and C. Nicole Ernsberger. 1989. "Public Pension Surpluses and National Saving: Foreign Experience.” New England Economic Review, March/April: 16-38.

Munnell, Alicia H., and Annika Sundén. 2001. "Investment Practices of State and Local Pension Plans," in Olivia Mitchell and Edwin Hustead (eds.), Pensions in the Public Sector (Philadelphia: The Pension Research Council and University of Pennsylvania Press, pp. 153-94).

Myers, Robert J., et al. 1988. The Social Security Benefit Notch: A Study (Washington, DC: National Academy of Social Insurance).

Poterba, James M., Steven F. Venti, and David A. Wise. 1998. "Personal Retirement Saving and Asset Accumulation: Reconciling the Evidence," in David Wise (ed.) Frontiers in the Economics of Aging (Chicago: University of Chicago Press, pp. 23-124).

President's Commission to Strengthen Social Security. 2002. Strengthening Social Security and Creating Personal Wealth for All Americans. (Washington: President's Commission to Strengthen Social Security). www.csss.gov/reports/

Quinn, Joseph F., Richard V. Burkhauser, and Daniel A. Myers. 1990. Passing the Torch: The Influence of Economic Incentives on Work and Retirement (Kalamazoo, MI: Upjohn).

Samwick, Andrew. 2000. "Is Pension Reform Conducive to Higher Saving?" Review of Economics and Statistics. 82(2): 264-72.

Smetters, Kent. 2002. "Is the Social Security Trust Fund Worth Anything?" Mimeo. (Philadelphia: University of Pennsylvania).

U.S. House of Representatives. 2000. The 2000 Green Book: Background Material and Data on Programs within the Jurisdicition of the Committee on Ways and Means. (Washington, DC: U.S. GPO).

U.S. Social Security Administration. 2000. Income of the Aged Chartbook, 1998. (Baltimore, MD: Social Security Administration). 
Table 1. Impact of Inreased Social Security Trust Fund Accumulation on Aggregate Savings, National Income, the Real Rate of Return, and Wages under Alternative Estimates of Government Saving Response /a/

\begin{tabular}{|c|c|c|c|c|c|c|c|}
\hline $\begin{array}{c}\begin{array}{c}\text { Offset: Effect of extra pension } \\
\text { saving on other government } \\
\text { saving } / \mathrm{b} /\end{array} \\
\end{array}$ & Year & Savings & GDP & NNP & $\begin{array}{c}\text { Consump- } \\
\text { tion }\end{array}$ & $\begin{array}{l}\text { Rate of } \\
\text { return }\end{array}$ & $\begin{array}{c}\text { Wage } \\
\text { rate }\end{array}$ \\
\hline \multirow[t]{6}{*}{$\beta=0.0$} & 2000 & 0.0 & 0.0 & 0.0 & 0.0 & 0.0 & 0.0 \\
\hline & 2010 & 24.9 & 1.0 & 0.4 & -1.0 & -0.9 & 1.2 \\
\hline & 2020 & 45.3 & 3.2 & 1.6 & -0.2 & -4.2 & 3.8 \\
\hline & 2025 & 54.3 & 4.4 & 2.3 & 0.2 & -6.0 & 5.2 \\
\hline & 2040 & 32.0 & 8.1 & 4.5 & 3.3 & -11.8 & 9.6 \\
\hline & 2050 & 29.5 & 8.9 & 5.1 & 4.2 & -12.7 & 10.4 \\
\hline \multirow[t]{6}{*}{$\beta=-0.65$} & 2000 & 0.0 & 0.0 & 0.0 & 0.0 & 0.0 & 0.0 \\
\hline & 2010 & 8.1 & 0.3 & 0.1 & -0.3 & -0.3 & 0.4 \\
\hline & 2020 & 14.5 & 1.1 & 0.6 & 0.0 & -1.5 & 1.3 \\
\hline & 2025 & 17.5 & 1.5 & 0.8 & 0.2 & -2.1 & 1.8 \\
\hline & 2040 & 9.5 & 2.7 & 1.7 & 1.3 & -4.2 & 3.2 \\
\hline & 2050 & 9.4 & 3.0 & 1.9 & 1.6 & -4.6 & 3.5 \\
\hline \multirow[t]{6}{*}{$\beta=-0.90$} & 2000 & 0.0 & 0.0 & 0.0 & 0.0 & 0.0 & 0.0 \\
\hline & 2010 & 2.5 & 0.1 & 0.0 & -0.1 & -0.1 & 0.1 \\
\hline & 2020 & 4.5 & 0.3 & 0.2 & 0.0 & -0.5 & 0.4 \\
\hline & 2025 & 5.4 & 0.5 & 0.3 & 0.1 & -0.7 & 0.6 \\
\hline & 2040 & 1.9 & 0.8 & 0.5 & 0.5 & -1.3 & 1.0 \\
\hline & 2050 & 3.1 & 0.9 & 0.6 & 0.5 & -1.4 & 1.0 \\
\hline
\end{tabular}

/a/ Under the assumed policy Social Security payroll taxes are periodically increased to maintain close actuarial balance over the 75-year planning horizon, yielding a much larger accumulation of trust fund reserves. See text.

/b/ See equation 1 in text.

Source: Authors' tabulations of macro growth simulation model as explained in text. 
Table 2. Impact of New Individual Retirement Account Fund Accumulation on Aggregate Savings, National Income, the Real Rate of Return, and Wages under Alternative Estimates of Private Saving Response /a/

Percent change compared with baseline values

\begin{tabular}{|c|c|c|c|c|c|c|c|}
\hline $\begin{array}{c}\text { Offset: Effect of additional } \\
\text { pension saving on total private } \\
\text { saving /b/ }\end{array}$ & Year & Savings & GDP & NNP & $\begin{array}{c}\text { Consump- } \\
\text { tion }\end{array}$ & $\begin{array}{l}\text { Rate of } \\
\text { return }\end{array}$ & $\begin{array}{l}\text { Wage } \\
\text { rate }\end{array}$ \\
\hline \multirow[t]{6}{*}{$\theta=1.0$} & 2000 & 0.00 & 0.00 & 0.00 & 0.00 & 0.00 & 0.00 \\
\hline & 2010 & 20.34 & 0.81 & 0.35 & -0.79 & -0.70 & 0.97 \\
\hline & 2020 & 31.00 & 2.51 & 1.33 & 0.05 & -3.40 & 2.97 \\
\hline & 2025 & 32.61 & 3.33 & 1.84 & 0.59 & -4.70 & 3.93 \\
\hline & 2040 & 21.37 & 4.86 & 2.98 & 2.20 & -7.32 & 5.68 \\
\hline & 2050 & 22.09 & 5.51 & 3.33 & 2.61 & -8.09 & 6.41 \\
\hline \multirow[t]{6}{*}{$\theta=0.5$} & 2000 & 0.00 & 0.00 & 0.00 & 0.00 & 0.00 & 0.00 \\
\hline & 2010 & 9.88 & 0.40 & 0.17 & -0.38 & -0.35 & 0.48 \\
\hline & 2020 & 14.74 & 1.23 & 0.67 & 0.07 & -1.70 & 1.46 \\
\hline & 2025 & 15.48 & 1.64 & 0.94 & 0.35 & -2.37 & 1.94 \\
\hline & 2040 & 11.12 & 2.49 & 1.56 & 1.16 & -3.83 & 2.90 \\
\hline & 2050 & 10.65 & 2.87 & 1.80 & 1.46 & -4.37 & 3.33 \\
\hline \multirow[t]{6}{*}{$\theta=0.1$} & 2000 & 0.00 & 0.00 & 0.00 & 0.00 & 0.00 & 0.00 \\
\hline & 2010 & 1.93 & 0.08 & 0.03 & -0.07 & -0.07 & 0.09 \\
\hline & 2020 & 2.83 & 0.24 & 0.14 & 0.02 & -0.34 & 0.29 \\
\hline & 2025 & 2.97 & 0.32 & 0.19 & 0.08 & -0.48 & 0.38 \\
\hline & 2040 & 2.32 & 0.51 & 0.33 & 0.24 & -0.79 & 0.59 \\
\hline & 2050 & 2.27 & 0.60 & 0.39 & 0.31 & -0.94 & 0.69 \\
\hline
\end{tabular}

/a/ Under the assumed policy Social Security payroll taxes are periodically increased to maintain close actuarial balance over the 75-year planning horizon, yielding a much larger accumulation of trust fund reserves. See text.

/b/ See equation 2 in text.

Source: Authors' tabulations of macro growth simulation model as explained in text. 
Table 3. Model Estimates of Labor Force Participation Relative to Participation Rates of 50-54 Year-Olds

\begin{tabular}{|c|c|c|c|c|c|c|c|c|c|c|c|c|}
\hline \multirow{2}{*}{$\begin{array}{r}\text { Age group: } \\
\text { Dependent variable: }\end{array}$} & \multicolumn{2}{|c|}{ Age 55-59 } & \multicolumn{2}{|c|}{ Age 60-64 } & \multicolumn{2}{|c|}{ Age 60-61 } & \multicolumn{2}{|c|}{ Age 62-64 } & \multicolumn{2}{|c|}{ Age 65-69 } & \multicolumn{2}{|c|}{ Age 70-74 } \\
\hline & $\begin{array}{c}\text { Current } \\
\text { LFP ratio } \\
\end{array}$ & $\begin{array}{c}\text { Lagged } \\
\text { LFP ratio } \\
\end{array}$ & $\begin{array}{c}\text { Current } \\
\text { LFP ratio } \\
\end{array}$ & $\begin{array}{c}\text { Lagged } \\
\text { LFP ratio } \\
\end{array}$ & $\begin{array}{c}\text { Current } \\
\text { LFP ratio } \\
\end{array}$ & $\begin{array}{c}\text { Lagged } \\
\text { LFP ratio } \\
\end{array}$ & $\begin{array}{c}\text { Current } \\
\text { LFP ratio } \\
\end{array}$ & $\begin{array}{c}\text { Lagged } \\
\text { LFP ratio } \\
\end{array}$ & $\begin{array}{c}\text { Current } \\
\text { LFP ratio } \\
\end{array}$ & $\begin{array}{c}\text { Lagged } \\
\text { LFP ratio } \\
\end{array}$ & $\begin{array}{c}\text { Current } \\
\text { LFP ratio } \\
\end{array}$ & $\begin{array}{c}\text { Lagged } \\
\text { LFP ratio } \\
\end{array}$ \\
\hline \multicolumn{13}{|l|}{ Men } \\
\hline Mean of dependent variable & 92.5 & 91.7 & 71.8 & 67.2 & 82.2 & 79.8 & 63.8 & 58.4 & 37.3 & 35.2 & 23.0 & 19.0 \\
\hline Constant & 102.6 & 97.2 & 103.9 & 98.8 & 106.4 & 101.4 & 104.7 & 100.4 & 71.3 & 73.2 & 44.8 & 63.9 \\
\hline Net replacement rate & $\begin{array}{l}-0.28 \\
(0.01)\end{array}$ & $\begin{array}{l}-0.26 \\
(0.02)\end{array}$ & $\begin{array}{l}-0.87 \\
(0.04)\end{array}$ & $\begin{array}{l}-0.78 \\
(0.05)\end{array}$ & $\begin{array}{l}-0.62 \\
(0.03)\end{array}$ & $\begin{array}{r}-0.57 \\
(0.03)\end{array}$ & $\begin{array}{l}-1.09 \\
(0.05)\end{array}$ & $\begin{array}{l}-0.97 \\
(0.07)\end{array}$ & $\begin{array}{l}-0.57 \\
(0.07)\end{array}$ & $\begin{array}{l}-0.26 \\
(0.10)\end{array}$ & $\begin{array}{l}-0.37 \\
(0.09)\end{array}$ & $\begin{array}{l}-0.09 \\
(0.10)\end{array}$ \\
\hline Time to eligibility & $\begin{array}{r}0.06 \\
(0.15)\end{array}$ & $\begin{array}{r}0.80 \\
(0.20)\end{array}$ & $\begin{array}{r}1.58 \\
(0.42)\end{array}$ & $\begin{array}{r}2.50 \\
(0.68)\end{array}$ & $\begin{array}{l}-1.16 \\
(0.27)\end{array}$ & $\begin{array}{r}0.22 \\
(0.48)\end{array}$ & $\begin{array}{r}1.15 \\
(0.51)\end{array}$ & $\begin{array}{r}2.74 \\
(0.88)\end{array}$ & $\begin{array}{r}2.67 \\
(0.59)\end{array}$ & $\begin{array}{r}5.64 \\
(0.77)\end{array}$ & $\begin{array}{r}0.88 \\
(0.64)\end{array}$ & $\begin{array}{r}3.98 \\
(0.90)\end{array}$ \\
\hline Adjusted R Square & 0.920 & 0.886 & 0.945 & 0.916 & 0.938 & 0.903 & 0.943 & 0.908 & 0.857 & 0.886 & 0.780 & 0.748 \\
\hline Number of observations & 47 & 47 & 47 & 38 & 47 & 40 & 47 & 37 & 47 & 40 & 47 & 28 \\
\hline \multicolumn{13}{|l|}{ Women } \\
\hline Mean of dependent variable & 86.4 & 92.1 & 59.8 & 66.5 & 70.4 & 78.1 & 51.7 & 57.8 & 28.6 & 30.1 & 14.8 & 17.5 \\
\hline Constant & 67.3 & 64.5 & 37.0 & 60.2 & 43.8 & 51.1 & 40.7 & 64.4 & 44.6 & 29.3 & 31.2 & 114.1 \\
\hline Net replacement rate & $\begin{array}{r}0.28 \\
(0.10)\end{array}$ & $\begin{array}{r}0.15 \\
(0.12)\end{array}$ & $\begin{array}{r}0.51 \\
(0.15)\end{array}$ & $\begin{array}{r}0.23 \\
(0.24)\end{array}$ & $\begin{array}{r}0.46 \\
(0.15)\end{array}$ & $\begin{array}{r}0.29 \\
(0.22)\end{array}$ & $\begin{array}{r}0.43 \\
(0.16)\end{array}$ & $\begin{array}{r}0.26 \\
(0.22)\end{array}$ & $\begin{array}{r}0.15 \\
(0.09)\end{array}$ & $\begin{array}{r}0.03 \\
(0.17)\end{array}$ & $\begin{array}{r}0.03 \\
(0.04)\end{array}$ & $\begin{array}{r}0.04 \\
(0.14)\end{array}$ \\
\hline Time to eligibility & $\begin{array}{r}1.12 \\
(1.35)\end{array}$ & $\begin{array}{r}4.40 \\
(1.57)\end{array}$ & $\begin{array}{r}6.67 \\
(2.07)\end{array}$ & $\begin{array}{l}12.38 \\
(3.26)\end{array}$ & $\begin{array}{r}3.42 \\
(2.00)\end{array}$ & $\begin{array}{l}11.54 \\
(3.01)\end{array}$ & $\begin{array}{r}7.22 \\
(2.18)\end{array}$ & $\begin{array}{l}13.84 \\
(2.97)\end{array}$ & $\begin{array}{r}4.50 \\
(0.75)\end{array}$ & & $\begin{array}{r}1.82 \\
(0.22)\end{array}$ & $\begin{array}{r}9.49 \\
(1.10)\end{array}$ \\
\hline Adjusted R Square & 0.153 & 0.153 & 0.236 & 0.323 & 0.168 & 0.301 & 0.211 & 0.427 & 0.451 & 0.001 & 0.602 & 0.760 \\
\hline Number of observations & 47 & 47 & 47 & 38 & 47 & 40 & 47 & 37 & 47 & 32 & 47 & 28 \\
\hline
\end{tabular}

Notes: Standard errors of coefficient estimates in parentheses. Data for "Current LFP ratio" cover 1950 and 1957-2002; a smaller number of years is available for "Lagged LFP ratio." 
Table 4. Predicted Change in Labor Force under Alternative Social Security Reforms and Assumptions, 2010-2040

Percent of labor force in baseline

\begin{tabular}{|c|c|c|c|c|c|c|}
\hline \multirow{2}{*}{$\begin{array}{c}\text { Reform / Year } \\
\end{array}$} & \multicolumn{6}{|c|}{ Age group } \\
\hline & $55-59$ & 60-64 & $65-69$ & $70-74$ & $55-74$ & 16 and older \\
\hline \multicolumn{7}{|l|}{ Men } \\
\hline \multicolumn{7}{|c|}{ Increase NRA to 67} \\
\hline 2010 & 1 & 4 & 5 & 2 & 3 & 0.4 \\
\hline 2020 & 1 & 6 & 5 & 6 & 4 & 0.7 \\
\hline 2030 & 2 & 9 & 10 & 11 & 6 & 1.1 \\
\hline 2040 & 2 & 9 & 10 & 11 & 6 & 1.1 \\
\hline \multicolumn{7}{|c|}{ Increase NRA to 70} \\
\hline 2010 & 2 & 7 & 5 & 2 & 4 & 0.6 \\
\hline 2020 & 3 & 14 & 14 & 12 & 9 & 1.7 \\
\hline 2030 & 5 & 21 & 22 & 21 & 14 & 2.6 \\
\hline 2040 & 5 & 21 & 25 & 28 & 15 & 2.7 \\
\hline \multicolumn{7}{|c|}{ Increase NRA to 67 and EEA to 64} \\
\hline 2010 & 1 & 7 & 6 & 2 & 4 & 0.6 \\
\hline 2020 & 2 & 11 & 19 & 11 & 8 & 1.5 \\
\hline 2030 & 2 & 13 & 24 & 19 & 11 & 2.0 \\
\hline 2040 & 2 & 13 & 24 & 20 & 10 & 1.9 \\
\hline \multicolumn{7}{|c|}{ Return to 1950 participation ratio } \\
\hline 2010 & 1 & 6 & 17 & 19 & 5 & 0.8 \\
\hline 2020 & 3 & 15 & 43 & 46 & 14 & 2.6 \\
\hline 2030 & 5 & 23 & 71 & 74 & 25 & 4.4 \\
\hline 2040 & 6 & 33 & 100 & 101 & 33 & 5.7 \\
\hline \multicolumn{7}{|l|}{ Women } \\
\hline \multicolumn{7}{|c|}{ Increase NRA to 67} \\
\hline 2010 & -1 & -3 & -2 & 0 & -2 & -0.3 \\
\hline 2020 & -1 & -4 & -2 & -1 & -2 & -0.4 \\
\hline 2030 & -2 & -5 & -3 & -1 & -3 & -0.6 \\
\hline 2040 & -2 & -5 & -3 & -1 & -3 & -0.5 \\
\hline \multicolumn{7}{|c|}{ Increase NRA to 70} \\
\hline 2010 & -2 & -4 & -2 & 0 & -2 & -0.4 \\
\hline 2020 & -3 & -9 & -5 & -1 & -5 & -0.9 \\
\hline 2030 & -5 & -13 & -7 & -2 & -8 & -1.3 \\
\hline 2040 & -5 & -13 & -8 & -3 & -8 & -1.4 \\
\hline \multicolumn{7}{|c|}{ Increase NRA to 67 and EEA to 64} \\
\hline 2010 & 2 & 11 & 2 & 0 & 4 & 0.7 \\
\hline 2020 & 1 & 19 & 30 & 14 & 11 & 2.1 \\
\hline 2030 & 1 & 17 & 29 & 23 & 12 & 2.0 \\
\hline 2040 & 1 & 17 & 29 & 23 & 11 & 1.9 \\
\hline \multicolumn{7}{|c|}{ Return to 1950 participation ratio } \\
\hline 2010 & 0 & 2 & 11 & 6 & 2 & 0.3 \\
\hline 2020 & -1 & 6 & 28 & 15 & 6 & 1.1 \\
\hline 2030 & -2 & 9 & 46 & 25 & 11 & 1.9 \\
\hline 2040 & -2 & 12 & 65 & 34 & 14 & 2.3 \\
\hline
\end{tabular}

Notes: "NRA" is normal retirement age (earliest age for unreduced retired-worker benefits) and "EEA" is early entitlement age (earliest age for an actuarially reduced retired-worker benefit).

Source: Authors' calculations based on "Current LFP ratio" results in Table 3 and Social Security Actuary's 2003 predictions of 2010-2040 population using intermediate assumptions. 
Figure 1. Change in Labor Force Participation Rates, 1910-2002

Men (1910-2002)

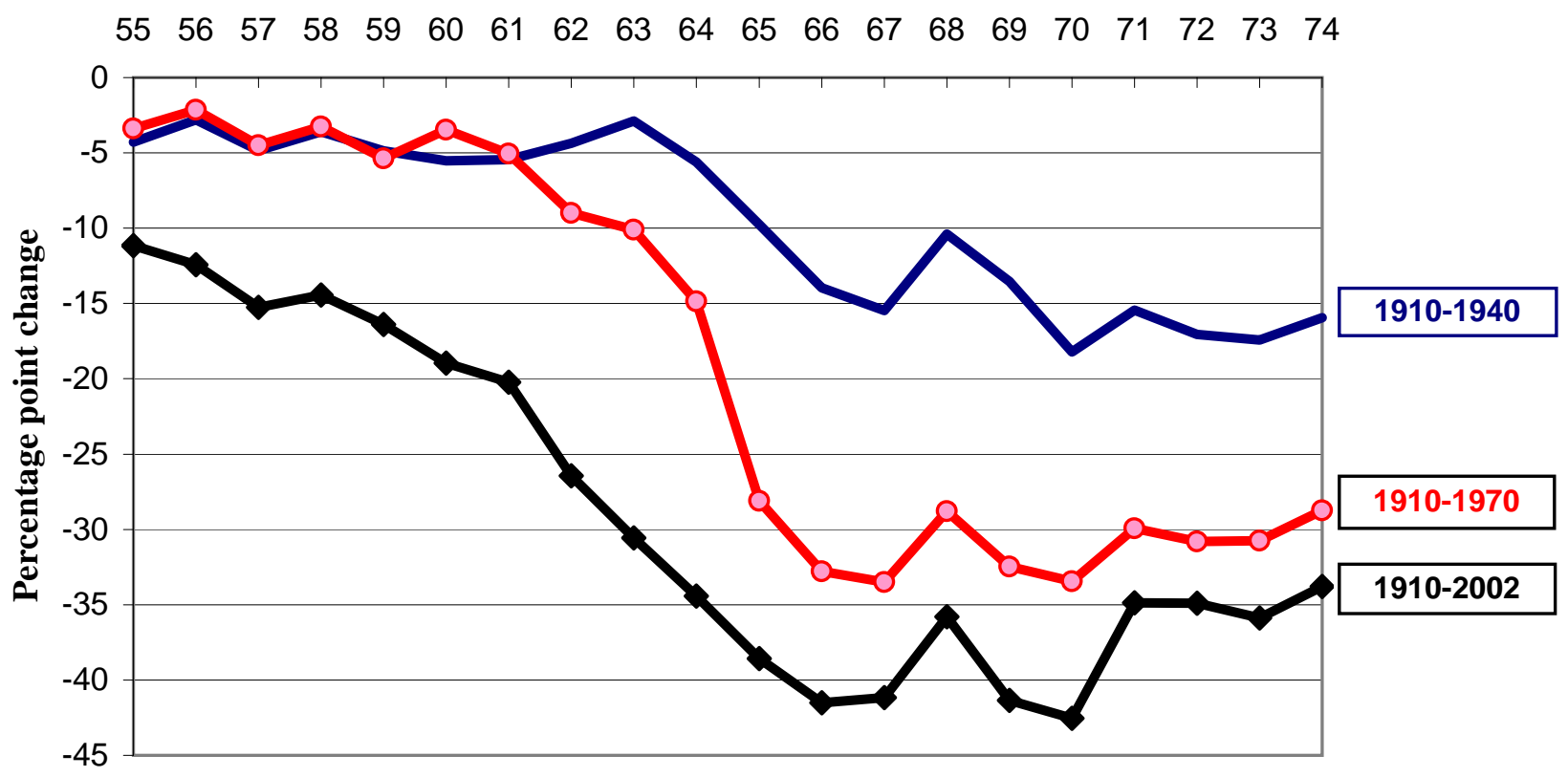

Women (1940-2002)

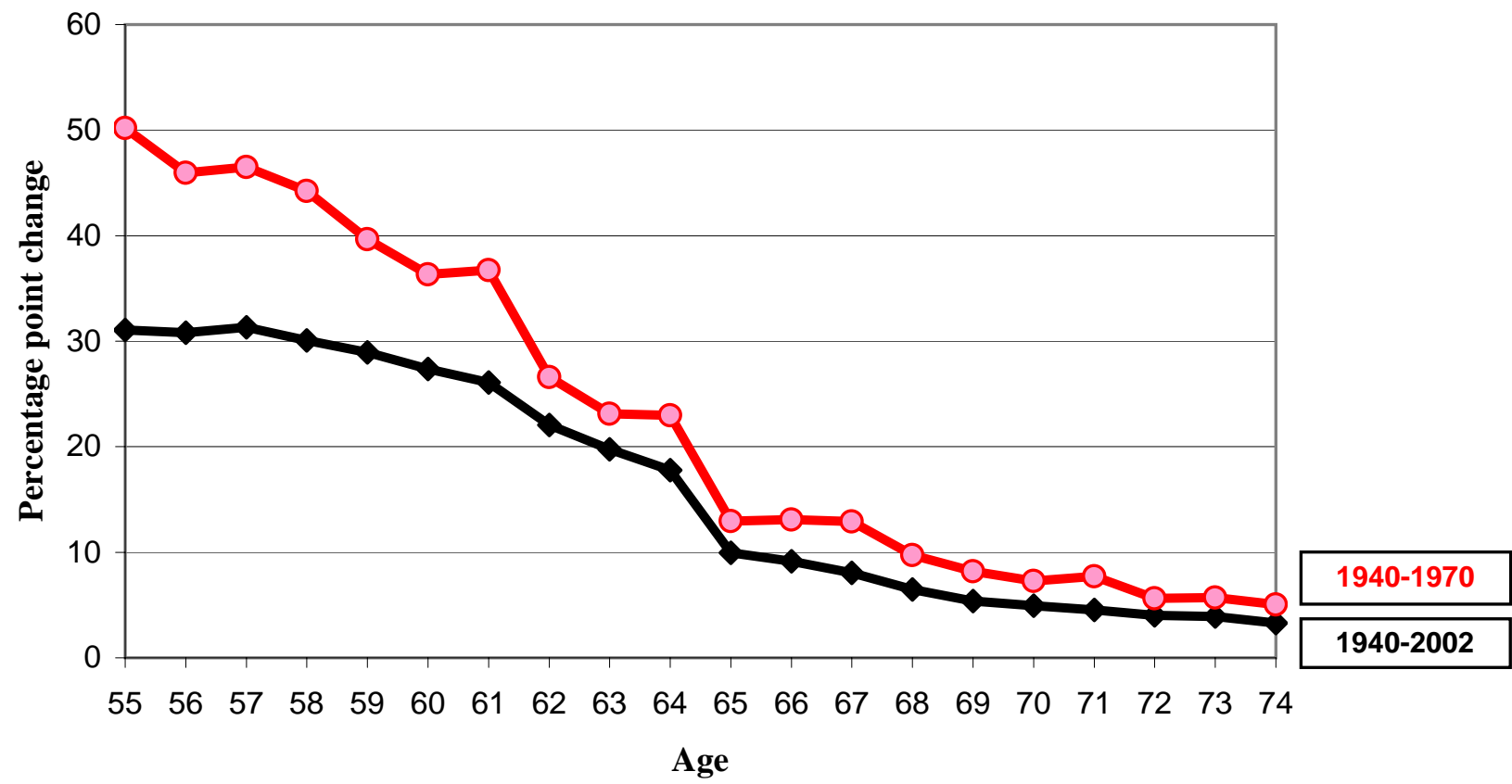

Source: Authors' tabulations of data from U.S. Bureau of the Census (1910-1970) and CPS files (1970 and 2002$).$ 
Figure 2. Labor Force Withdrawal among 1906-1930 Birth Cohorts, by Gender

Labor force participation as percent of rate between ages 50-54

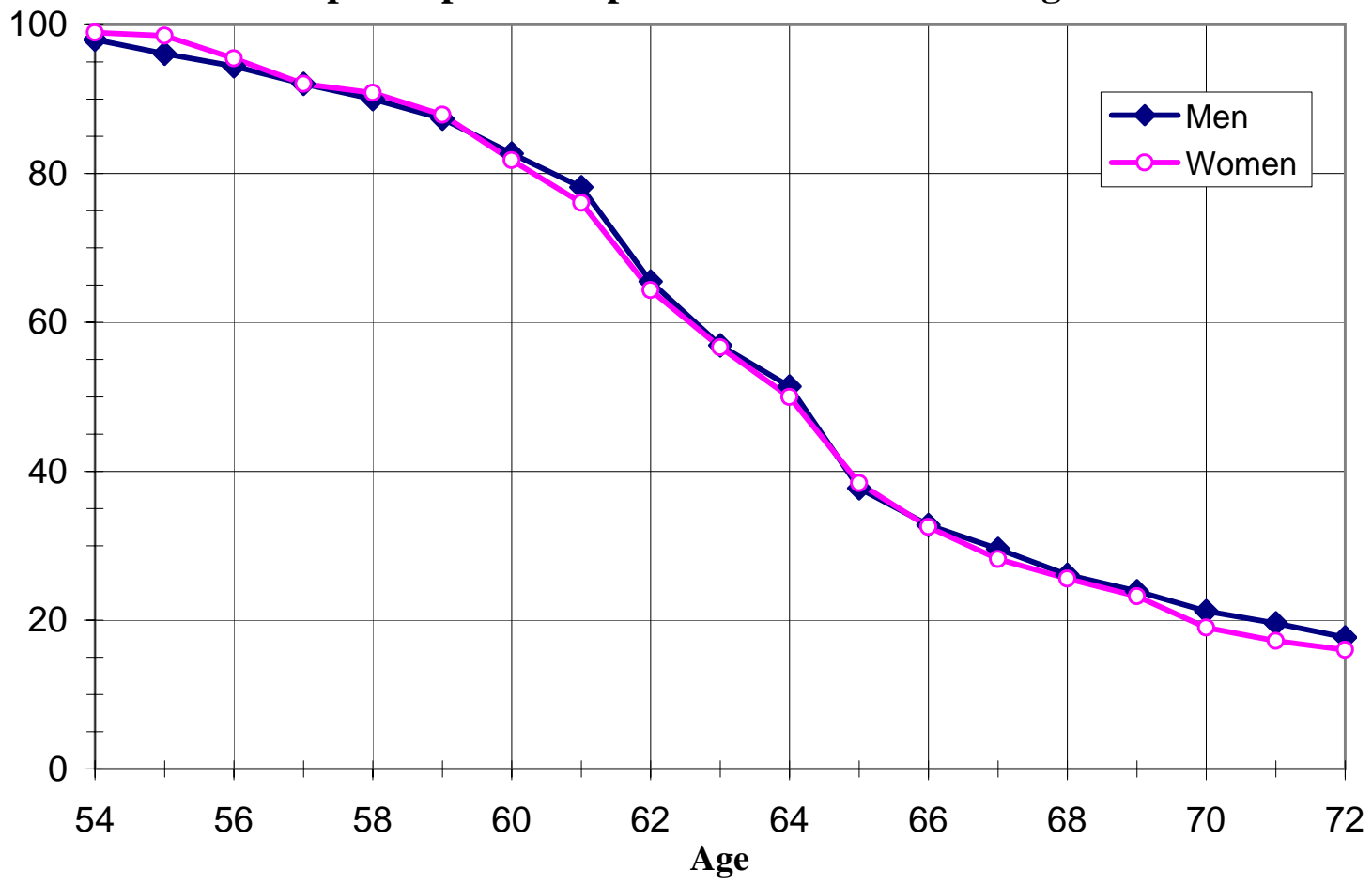

Retirement rate: Percent withdrawing as percent of participation rate between ages 50-

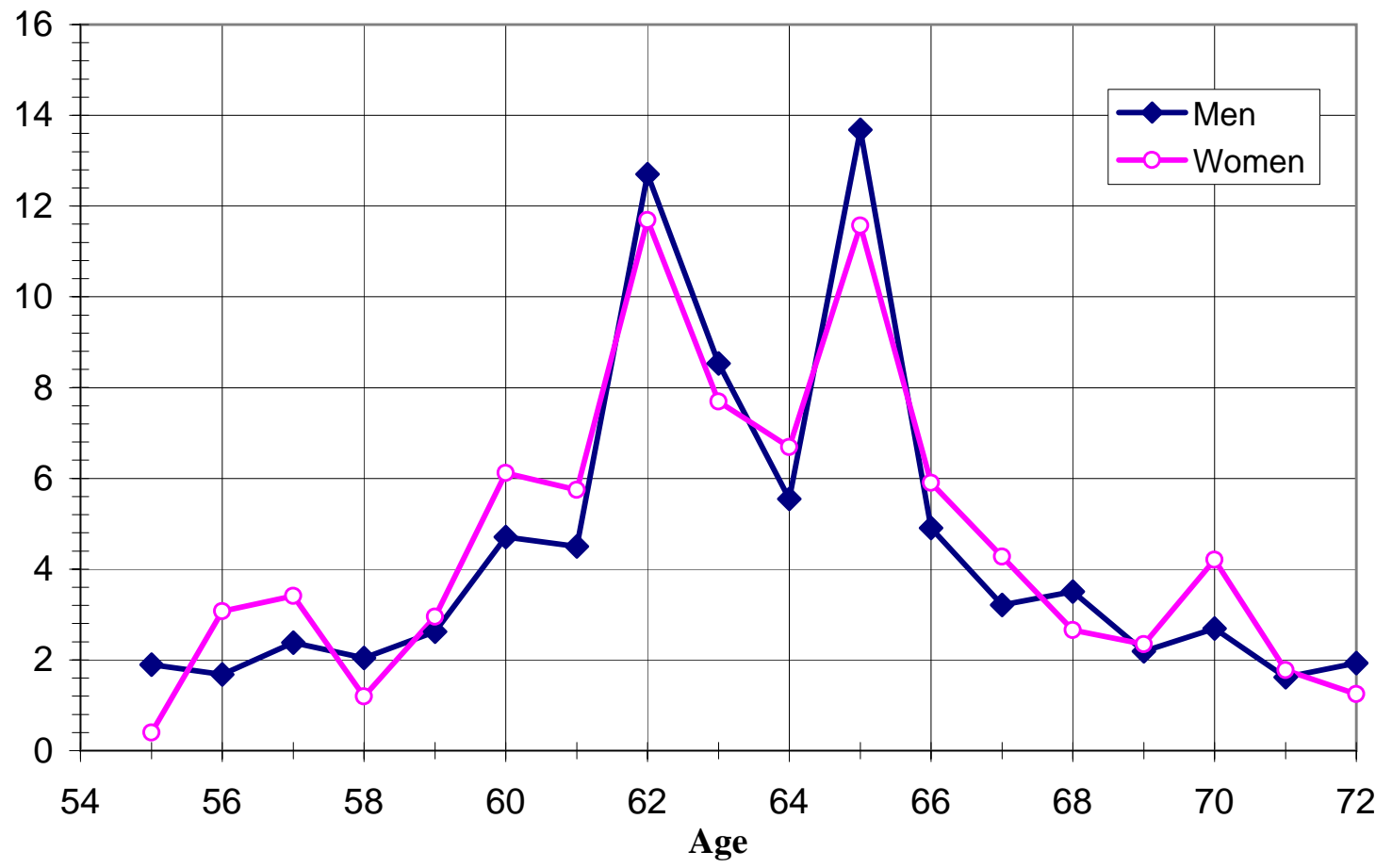

Source: Authors' tabulations of data from March CPS files (1962-1975) and monthly CPS files (1976-2002). 
Figure 3. Labor Force Participation Rate as a Fraction of the Participation Rate of 50-54 Year-Old Women

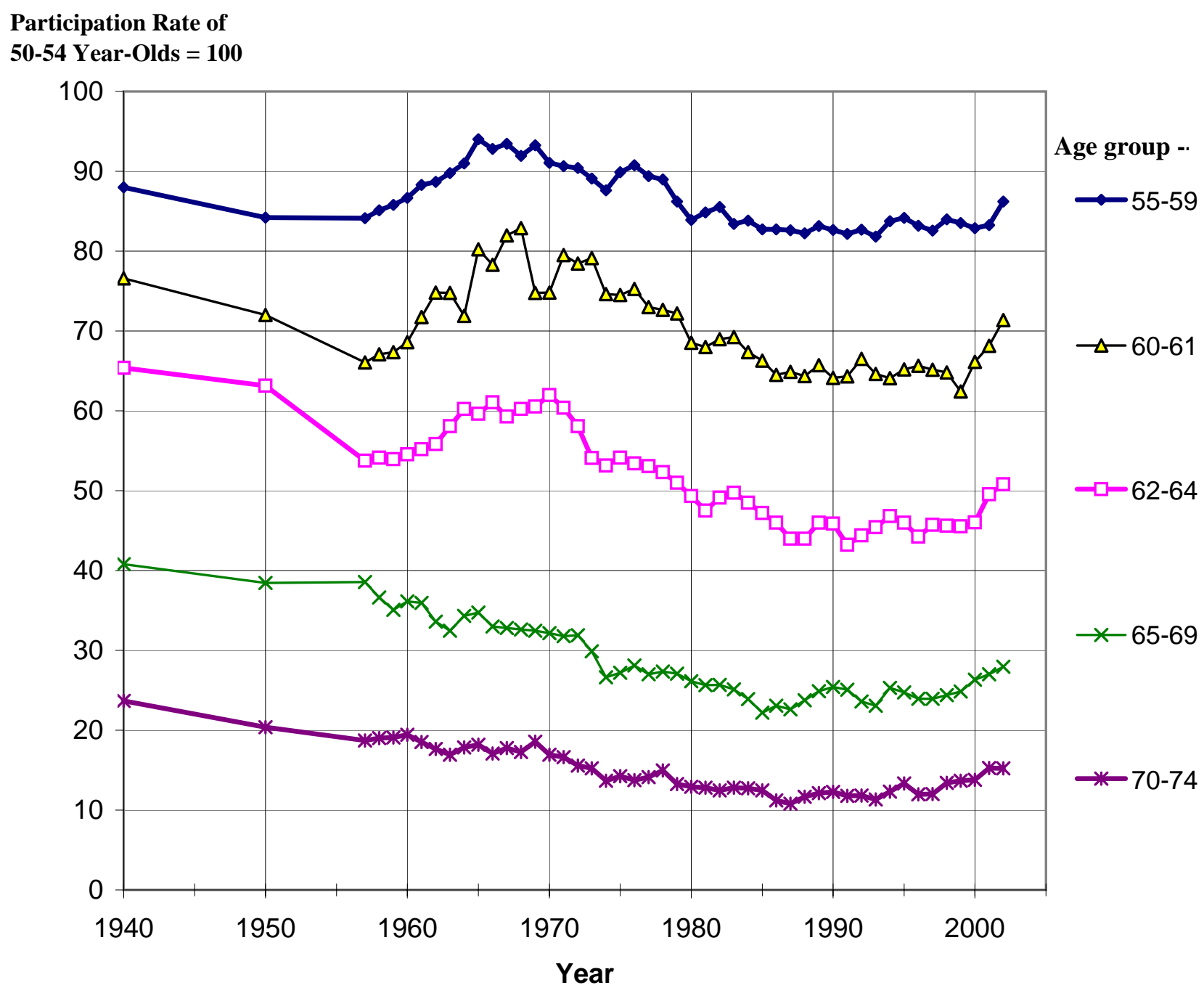

Source: BLS and authors' tabulations of data from U.S. Bureau of the Cenus (1940-1960) and monthly CPS files (1962-2002) 
Figure 4. Labor Force Participation Rate as a Fraction of the Participation Rate of 50-54 Year-Old Men

\section{Men aged 55-64}

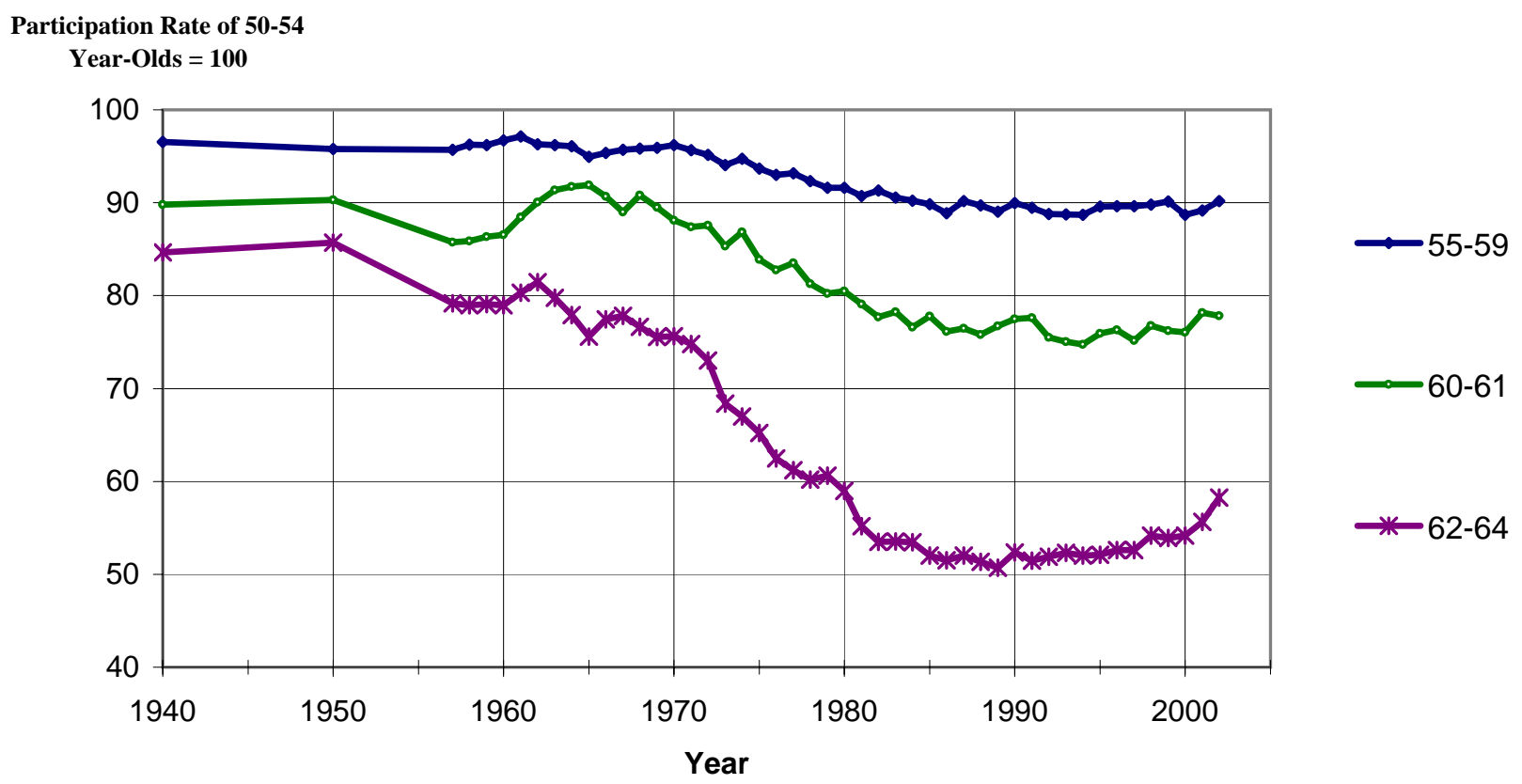

Participation Rate of 50

Men aged 65-74

54 Year-Olds $=100$

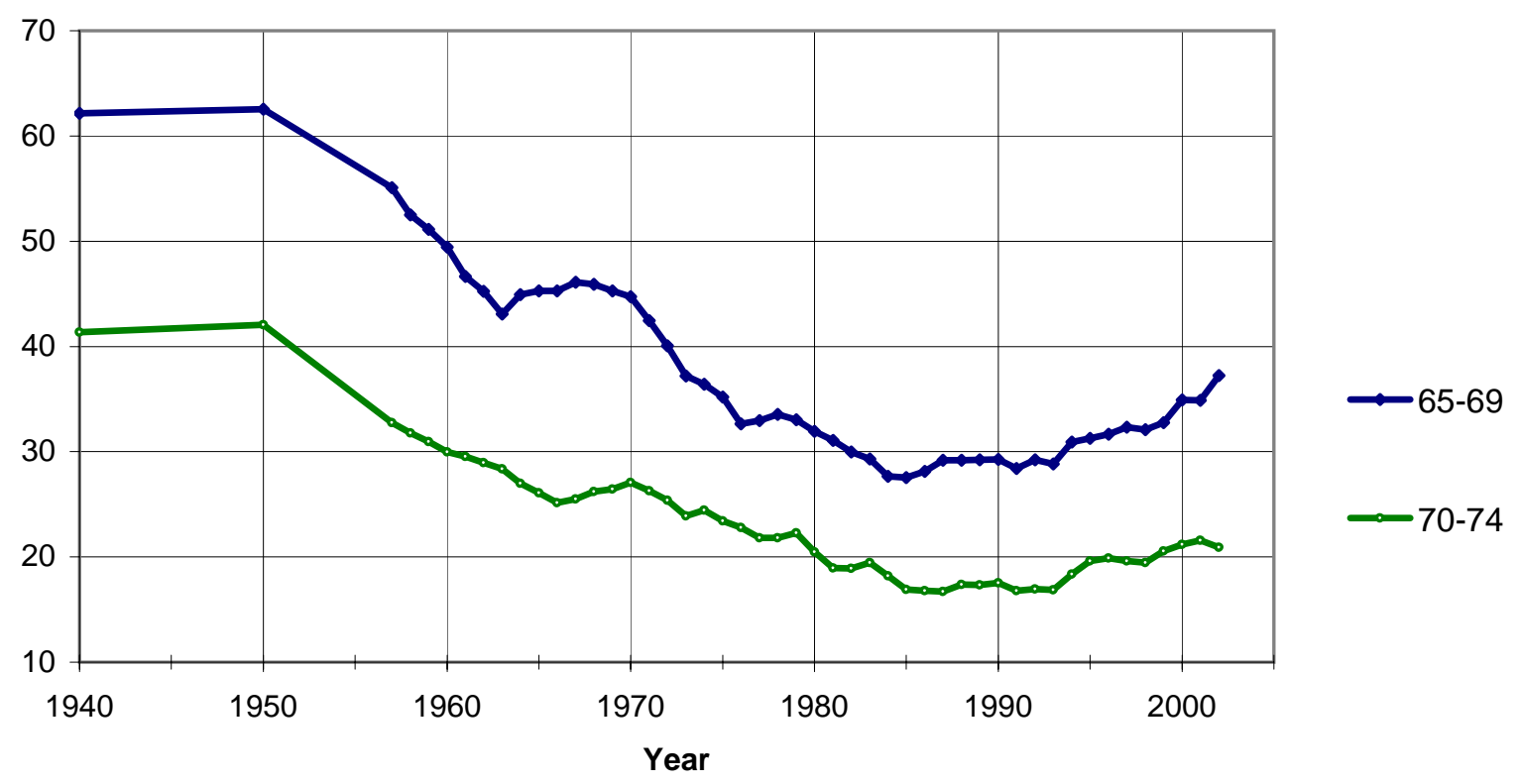

Source: BLS and authors' tabulations of data from U.S. Bureau of the Cenus (1940-1960) and monthly CPS files (1962-2002) 


\section{Figure 5. Social Security Retired Worker Replacement Rates, 1950-2002}
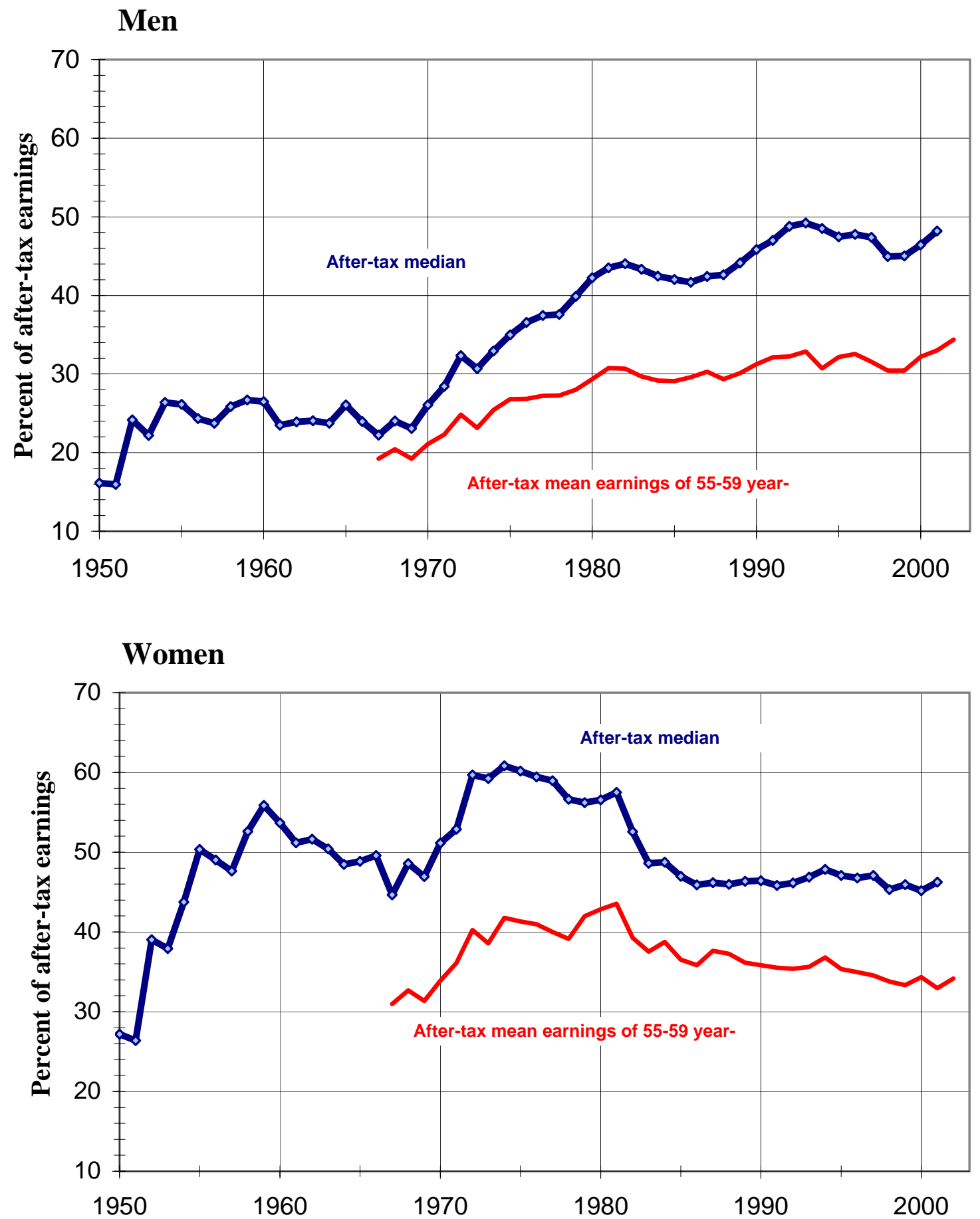

Note: The replacement rate is measured as the ratio of the average newly awarded PIA to net median or mean earnings, where the net wage is the gross wage minus workers' payroll tax contributions for OASDHI.

Sources: PIA from Social Security Bulletin, Annual Statistical Supplement (various years); median earnings from U.S. Bureau of the Census; mean earnings of 55-59 year-olds from authors' tabulations of March CPS files, 1968-2003. 
Figure 6. Percentage of Persons 65-69 Eligible for and Receiving RetiredWorker Benefits, 1950-2001

Eligible for retired-worker benefits

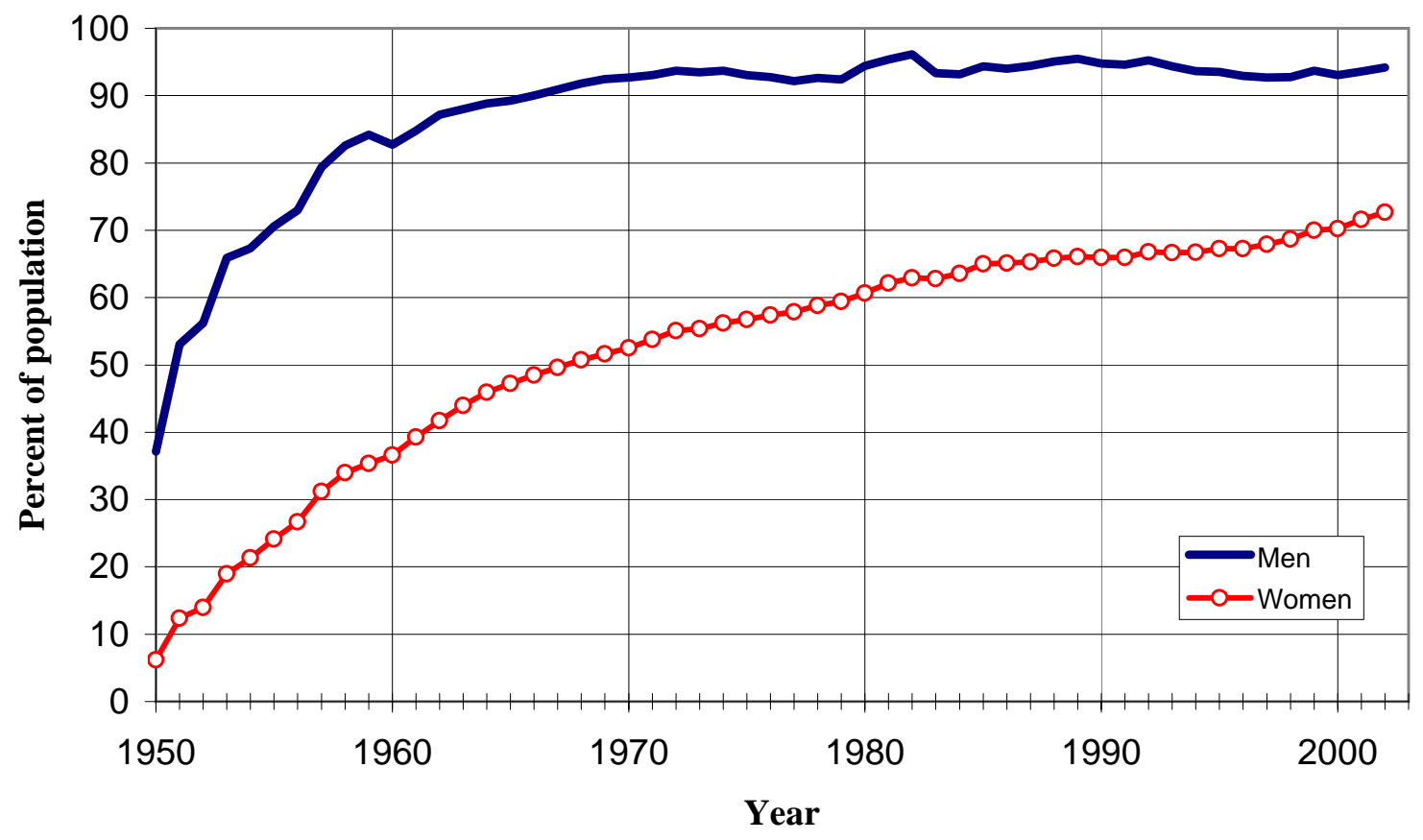

Receiving retired-worker benefits

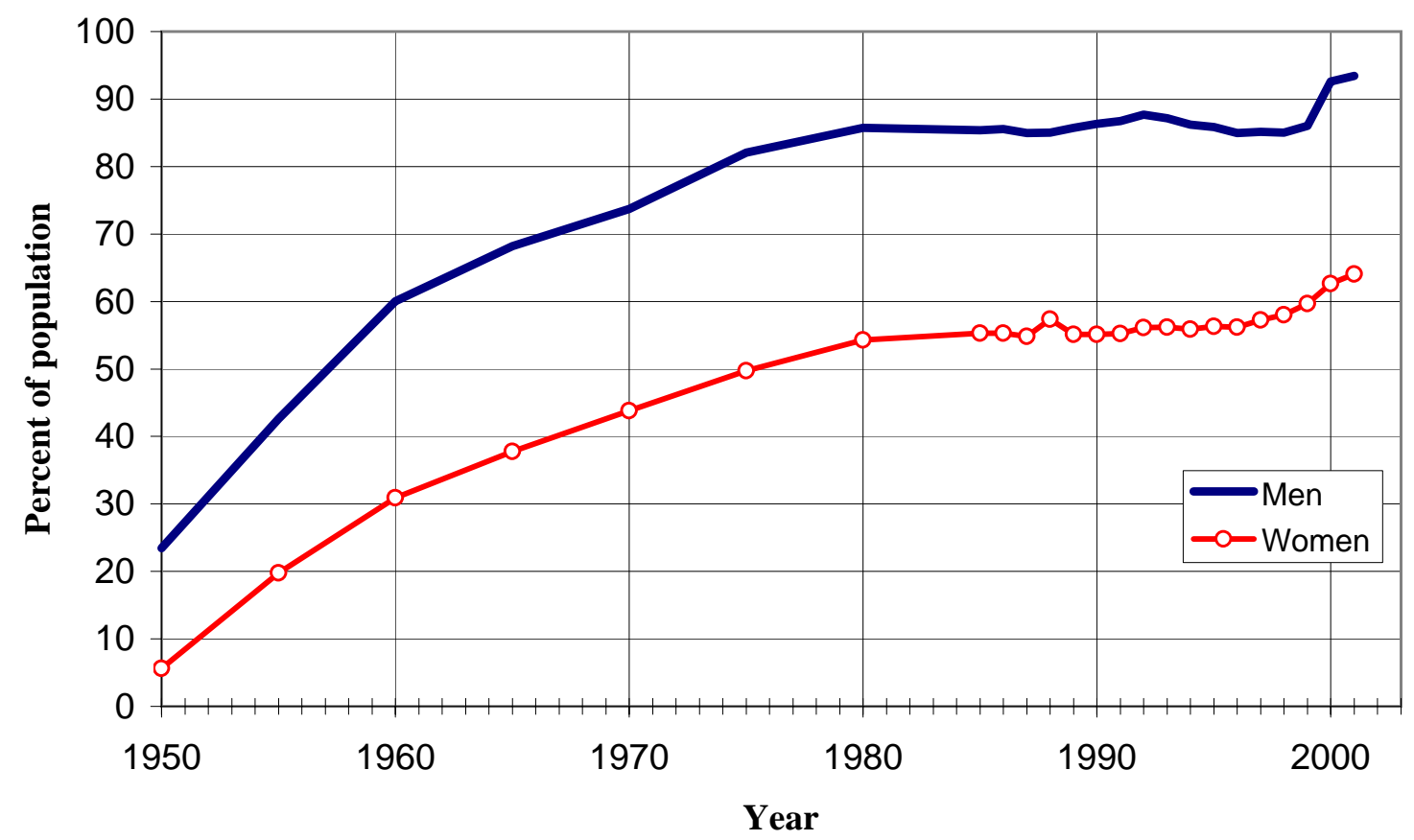

Sources: Authors' tabulations of data from Social Security Bulletin, Annual Statistical Supplement (various years) and U.S. Bureau of Census. 


\section{RECENT WORKING PAPERS FROM THE \\ Center For Retirement Research at Boston College}

Simulating the Distributional Consequences of Personal Accounts: Sensitivity to Annuitization Options

Cori E. Uccello, Melissa M. Favreault, Karen E. Smith, and Lawrence H. Thompson, October 2003

Aggregate Implications of Defined Benefit and Defined Contribution Systems

Francisco Gomes and Alexander Michaelides, September 2003

Can Unexpected Retirement Explain the Retirement-Consumption Puzzle?

Evidence for Subjective Retirement Explanations

Melvin Stephens Jr. and Steven J. Haider, August 2003

Employment, Social Security and Future Retirement Outcomes for Single Mothers Richard W. Johnson, Melissa M. Favreault, and Joshua H. Goldwyn, July 2003

The Outlook for Pension Contributions and Profits in the U.S.

Alicia H. Munnell and Mauricio Soto, June 2003

Social Security Reform and the Exchange of Bequests for Elder Care

Meta Brown, June 2003

Annuities and Individual Welfare

Thomas Davidoff, Jeffrey Brown, and Peter Diamond, May 2003

Becoming Oldest-Old: Evidence for Historical U.S. Data

Dora Costa and Joanna Lahey, May 2003

The Evolution of Social Security Disabled Widow(er)s' Benefits

Eric R. Kingson, Margaret Morse, and Gary Calhoun, May 2003

Health Shocks and Couples' Labor Supply Decisions

Courtney Coile, May 2003

Whose Money is It Anyhow?: Governance and Social Investment in Collective Investment Funds

R. Kent Weaver, May 2003

The Politics of Public Pension Reform

R. Kent Weaver, May 2003

All working papers are available on the Center for Retirement Research website (http://www.bc.edu/crr) and can be requested by e-mail (crr@bc.edu) or phone (617-552-1762). 